\title{
Variscan granitoid plutonism in the Strzelin Massif (SW Poland): petrology and age of the composite Strzelin granite intrusion
}

\author{
Teresa OBERC-DZIEDZIC ${ }^{1, *}$, Ryszard KRYZA ${ }^{1}$, Christian PIN $^{2}$ \\ and Stanisław MADEJ ${ }^{1}$ \\ 1 Institute of Geological Sciences, University of Wrocław, M. Borna 9, 50-204 Wrocław, Poland \\ 2 Département de Géologie, CNRS, Université Blaise Pascal, 5 rue Kessler, 63038 Clermont-Ferrand Cedex, France
}

Oberc-Dziedzic T., Kryza R., Pin C. and Madej S. (2013) Variscan granitoid plutonism in the Strzelin Massif (SW Poland): petrology and age of the composite Strzelin granite intrusion. Geological Quarterly, 57 (2): 269-288, doi: 10.7306/gq.1083

Petrological data and recently published U/Pb zircon SHRIMP ages reveal a protracted Variscan magmatic evolution in the Strzelin Massif (SW Poland), with three main stages of granitoid plutonism: 1 - tonalitic I, 2 - granodioritic and 3 - tonalitic II/granitic. The granitoids of the second and third stages form the Strzelin intrusion that is composed of three varieties: medium-grained biotite granite, fine-grained biotite granite and fine-grained biotite-muscovite granite. New SHRIMP data show that the medium-grained and fine-grained biotite granites comprise different zircon populations that reflect complex and prolonged plutonic processes. Two distinct magmatic events seem to be represented by well-defined zircon populations with apparent ${ }^{206} \mathrm{~Pb} /{ }^{238} \mathrm{U}$ ages of $303 \pm 2 \mathrm{Ma}$ in the medium-grained biotite granite, and $283 \pm 8 \mathrm{Ma}$ in the fine-grained biotite granite. These dates, however, do not necessarily reflect the true magmatic ages, possibly being "rejuvenated" by radiogenic lead loss in zircons (impossible to resolve based on routine SHRIMP data). Based on field evidence, the third variety, the biotite-muscovite granite, postdates both types of biotite granites. The petrographic and geochemical features, including Nd isotope signature, along with various zircon inheritance patterns and ages, suggest that the parental magmas of the three granites originated from different crustal sources and were emplaced during three successive magmatic pulses.

Key words: zircon SHRIMP geochronology, composite granitoid plutons, Variscan granitoids, Strzelin Massif.

\section{INTRODUCTION}

The Variscan orogenic belt in Central Europe abounds in granitoids differing in petrography, geochemistry and sources, and that were formed in several magmatic events, between 370 and $250 \mathrm{Ma}$ (Finger et al., 1997) or between 340 and $270 \mathrm{Ma}$ (Schaltegger, 1997). The granitoid intrusions are widespread and large in the Moldanubian Zone (Fig. 1A), less abundant and smaller in the Teplá-Barrandian and Saxothuringian zones, and rare in the Rhenohercynian Zone (e.g., Franke and Żelaźniewicz, 2002 and references therein).

The Variscan granitoids occur also in the Sudetes, in the northeasternmost part of the Central European Variscides (Fig. 1B). The Sudetes (together with the Fore-Sudetic Block) comprise fragments of two larger crustal blocks: the Bohemian Massif (in the West and Central Sudetes) and Brunovistulicum (in the East Sudetes). Variscan granitoid plutons are abundant in the West Sudetes, correlative with the Saxothuringian Zone,

\footnotetext{
* Corresponding author: teresa.oberc-dziedzic@ing.uni.wroc.pl Received: July 9, 2012; accepted: January 23, 2013; first published online: April 23, 2013
}

and in the Central Sudetes, interpreted as corresponding to the Teplá-Barrandian and Moldanubian zones (Mazur et al., 2006; Franke, 2012). Granitoid magmatism in the West Sudetes is dated between 322-300 Ma (Turniak et al., 2005; Kryza et al., 2012) and in the Central Sudetes at around 350-330 Ma (Mazur et al., 2007). In Brunovistulicum, the Variscan granitoids are restricted to the northern and central segments of its marginal part, i.e. to the East Sudetes (Fig. 1B). In the northernmost segment of Brunovistulicum, in the Strzelin Massif (Fig. 1B, C), the Variscan granitoids have been dated at 347-330 Ma (Oberc-Dziedzic et al., 1996; Rb-Sr method); 301-291 Ma (Turniak et al., 2006; Pb-evaporation zircon method); $295 \mathrm{Ma}$ (Pietranik and Waight, 2008; Rb-Sr method); 324-295 Ma (Oberc-Dziedzic et al., 2010, Oberc-Dziedzic and Kryza, 2012; SHRIMP method). Farther to the south, they form the relatively large Žulová Pluton (Fig. 1B; Cháb and Žaček, 1994) and small bodies south of it (Cháb et al., 1994).

In the Strzelin Massif (Fig. 1C), the Variscan granitoid plutonism shows several features different from the Variscan magmatism in other parts of the Sudetes:

- it produced numerous small plutonic bodies and not single large intrusions such as, e.g., the Karkonosze Pluton or the Strzegom-Sobótka Pluton in the West Sudetes (Fig. 1B);

- in many cases, petrographically similar rocks have different geochemical characteristics and ages; 

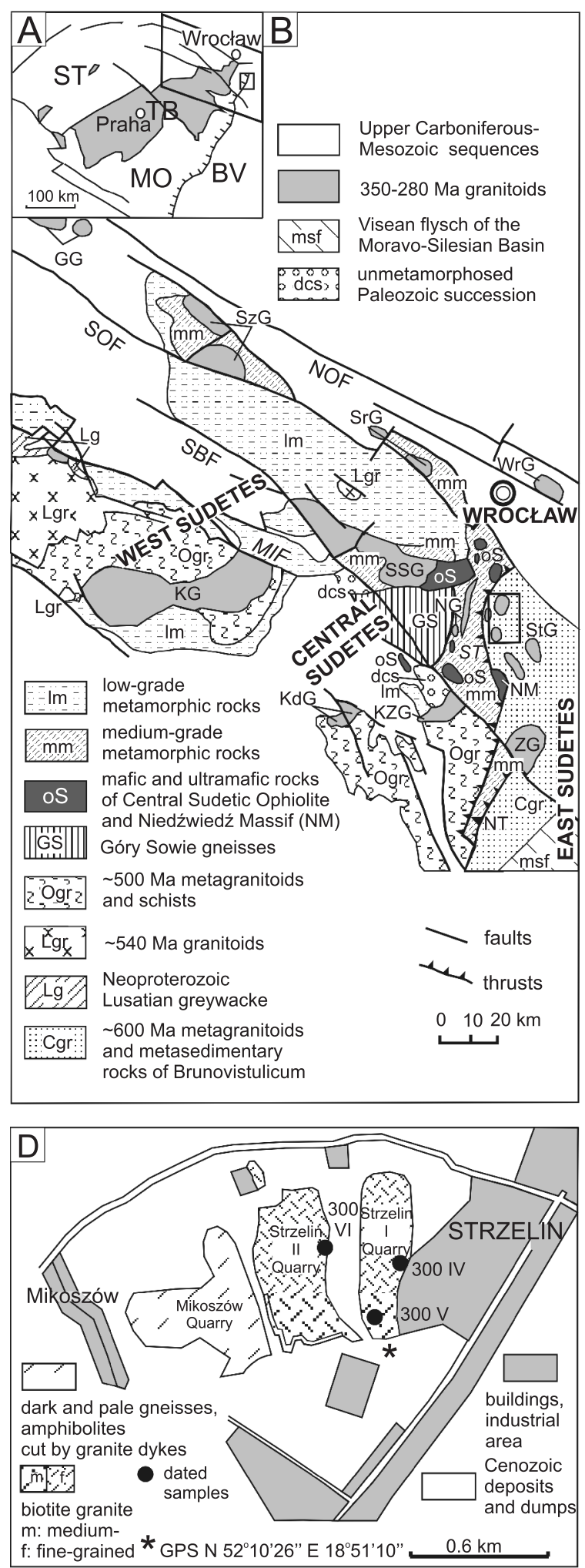

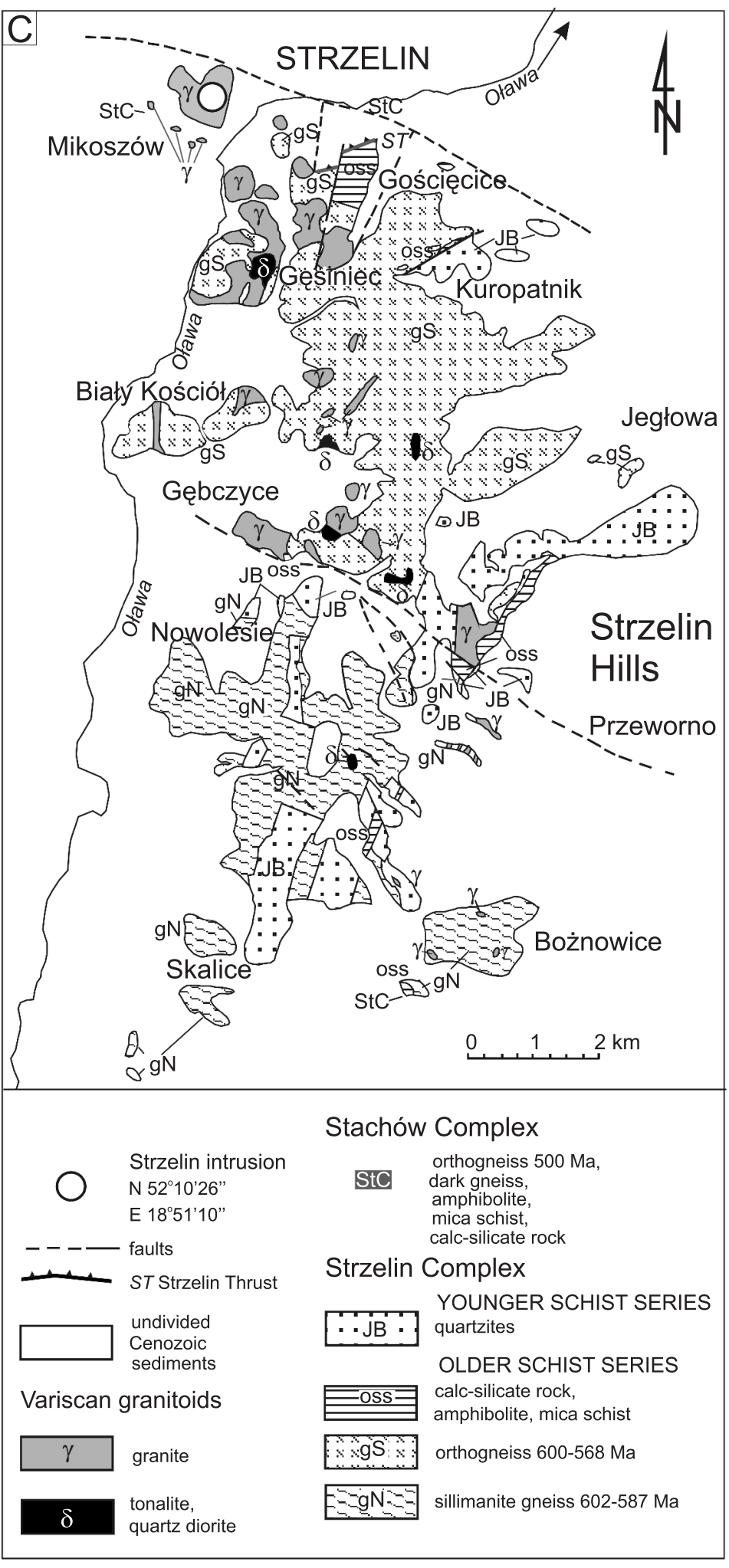

Fig. 1. Geological position of the Strzelin Massif and the Strzelin intrusion

A - sketch map of the Bohemian Massif (ST - Saxothuringian, TB - Teplá-Barrandian, MO - Moldanubian zones, after Franke, 2012) and Brunovistulicum (BV); large and small quadrangles show the location of the Sudetes and the Strzelin Massif, respectively; B - granitoids of the Sudetes, Fore-Sudetic Block and Odra Fault Zone; Odra Fault Zone: GG - Gubin, SrG - Środa Ślasska, SzG - Szprotawa, WrG Wrocław; Fore-Sudetic Block: NG - Niemcza, SSG - Strzegom-Sobótka, StG - Strzelin, ZG - Žulová; Sudetes: KdG - Kudowa, KG Karkonosze, KZG - Kłodzko-Złoty Stok; faults: MIF - Main Intra-Sudetic Fault, SBF - Sudetic Boundary Fault, SOF - Southern Odra Fault, NOF - Northern Odra Fault; thrusts: NT - Nyznerov Thrust, ST - Strzelin Thrust (separating the Stachów and Strzelin complexes); rectangle shows the position of the Strzelin Massif; C - geological map of the eastern part of the Strzelin Massif (after Oberc et al., 1988); D - location of quarries in Strzelin 
- tonalites and quartz diorites are more widespread and, locally (in the $\mathrm{S}$ part), prevail over the granites (Oberc-Dziedzic, 2007);

- Variscan granitoid plutonism lasted at least $\sim 30$ m.y. longer in the Strzelin Massif than in other parts of Sudetes (Oberc-Dziedzic et al., 2010).

In our earlier contributions (Oberc-Dziedzic et al., 2010, Oberc-Dziedzic and Kryza, 2012), we provided evidence for three stages of the Variscan granitoid magmatism in the Strzelin Massif: 1) tonalitic I - ca. $324 \mathrm{Ma}$, 2) granodioritic - ca. $305 \mathrm{Ma}$ and 3) tonalitic II /granitic - ca. $295 \mathrm{Ma}$, and we described petrographic and geochemical features of the tonalites and granodiorites. This study is devoted to the granites of the Strzelin intrusion, the largest magmatic body in the northern part of the Strzelin Massif, representing the second and third stages of the Variscan magmatism. Based on field observations, petrographic and geochemical features and new SHRIMP zircon age data, we document the emplacement of these granites during three successive magma pulses within the formation of the composite Strzelin intrusion.

\section{GEOLOGICAL SETTING}

The Sudetes, representing the northeasternmost part of the Central European Variscides, are located between two parallel WNW-ESE trending fault zones: the Upper Elbe Zone on the SW and the Odra Fault Zone on the NE (Fig. 1B). They are subdivided into the mountainous part - the Sudetic Block and the lowland part - the Fore-Sudetic Block, separated by the NW-SE trending Sudetic Boundary Fault. The Sudetes are further subdivided into the West and Central Sudetes, both linked with the Bohemian Massif, and the East Sudetes, which belongs to Brunovistulicum. The three parts of the Sudetes differ in their lithostratigraphy, structure and geological evolution (Mazur et al., 2006). The location, extent and correlations of the major tectono-stratigraphic zones of the Variscan Belt (or "terranes" of Matte et al., 1990, that belong to the Armorican Terrane Assemblage of Franke, 2000), i.e. Moldanubian, Saxothuringian (Kossmat, 1927) and TepláBarrandian (Franke, 1989, 2012) zones, in the West and Central Sudetes is still a matter of discussion (e.g., Franke et al., 1993; Cymerman and Piasecki, 1994; Cymerman et al., 1997; Franke and Żelaźniewicz, 2000, 2002; Aleksandrowski and Mazur, 2002).

According to Mazur et al. (2006), the Central Sudetes were deformed during the Middle/Late Devonian, the West Sudetes around the Devonian-Carboniferous boundary, and the East Sudetes during the Early Carboniferous.

The oblique collision of the Moldanubian Zone (the Bohemian Massif) with Brunovistulicum (Bruno-Vistulicum after Dudek, 1980) of Avalonian affinity (Finger et al., 2000; Friedl et al., 2000) took place in the Early to Late Carboniferous (Schulmann and Gayer, 2000). During this collision, the marginal part of Brunovistulicum, composed of Neoproterozoic granites, together with their sedimentary cover, was deformed into the nappe piles of the Moravo-Silesian Zone (e.g., Finger et al., 1989; Franke and Żelaźniewicz, 2000; Mazur et al., 2006). The rocks of the Moravo-Silesian Zone, in its northern part, are ex- posed in the Silesian domain (e.g., Schulmann and Gayer, 2000) which belongs to the East Sudetes. The Brunovistulicum basement can be traced further north, in the Strzelin Massif in the eastern part of the Fore-Sudetic Block (Oberc-Dziedzic et al., 2003).

The boundary between the Moldanubian Zone and Brunovistulicum was recognized by Suess $(1912,1926)$ and defined as the Moldanubian Overthrust. The Nyznerov Thrust (Skácel, 1989) in the Silesian domain, and the Strzelin Thrust (ObercDziedzic et al., 2005; Żelaźniewicz and Aleksandrowski, 2008; Fig. 1B) in the eastern part of the Fore-Sudetic Block are regarded as the NE continuations of the Moldanubian Overthrust.

The Strzelin Massif is situated in the eastern part of the Fore-Sudetic Block, $35 \mathrm{~km}$ south of Wrocław (Fig. 1B, C). The massif comprises fragments of Moldanubicum (sensu Aleksandrowski and Mazur, 2002; Mazur et al., 2006) and of Brunovistulicum, separated in this area by the Strzelin Thrust (ObercDziedzic and Madej, 2002; Oberc-Dziedzic et al., 2005, 2010). The footwall of the Strzelin Thrust - the lower tectonic unit - is composed of the Strzelin Complex belonging to Brunovistulicum, whereas the hanging wall - the upper tectonic unit - is composed of the Stachów Complex correlated with Moldanubicum (Oberc-Dziedzic and Madej, 2002; Oberc-Dziedzic et al., 2005, 2010).

The Strzelin Complex comprises:

1 - gneisses of ca. 600-570 Ma (Oberc-Dziedzic et al., 2003; Klimas, 2008; Klimas et al., 2009; Mazur et al., 2010);

2 - the older schist series containing mica schists, amphibolites, calc-silicate rocks and marbles of unknown age;

3 - the younger schist series - the Jegłowa Beds (Oberc, 1966) - composed of quartzites, quartz-sericite schists and metaconglomerates correlative with the Lower-Middle Devonian quartzites of the Silesian domain (Oberc, 1966; Patočka and Szczepański, 1997).

The Stachów Complex is composed of orthogneisses, ca. $500 \mathrm{Ma}$ in age (Oliver et al., 1993; Klimas, 2008; Mazur et al., 2010) and dark paragneisses associated with biotite-amphibole schists and amphibolites (Oberc-Dziedzic and Madej, 2002). The rocks of both complexes were metamorphosed and deformed during the Variscan orogeny (Oberc-Dziedzic et al., 2010). The rocks of the Stachów Complex form the western part of the Strzelin Massif, and klippens in the vicinity of Strzelin (Fig. 1C, D). The rocks of the Strzelin Complex crop out in the eastern part of the massif and as a tectonic window in its western part.

Both metamorphic complexes of the Strzelin Massif were intruded by Variscan granitoids. The Strzelin intrusion proper (Fig. 1C, D) is situated close to the morphological edge (possibly reflecting a fault) which borders from the north the hilly area of the Strzelin Massif crystalline rocks, from the flat area further north, covered by thick Cenozoic deposits. The intrusion is composed of three successive granite varieties:

- medium-grained biotite granite;

- fine-grained biotite granite;

- fine-grained biotite-muscovite granite.

All granitoids are cut by thin veins of aplite. The granites yielded relatively old Rb-Sr whole-rock ages: $347 \pm 12$ Ma for the biotite granites, and $330 \pm 6 \mathrm{Ma}$ for the two-mica granite 
(Oberc-Dziedzic et al., 1996). A significantly younger ${ }^{207} \mathrm{~Pb} /{ }^{206} \mathrm{~Pb}$ apparent age of $301 \pm 7$ Ma was obtained for the biotite granites by the zircon $\mathrm{Pb}$ evaporation method (Turniak et al., 2006) ${ }^{1}$.

\section{FIELD RELATIONSHIPS}

Field relationships of the Strzelin intrusion granites and their country rocks have been described based on observations from three large, active quarries: Strzelin I (Figs. 1D and 2) in the eastern part, and Strzelin II and Mikoszów in the western part of the intrusion, as well as from 24 boreholes, 100-120 m deep, drilled for granite prospecting during the 1980's. The metamorphic envelope of the Strzelin granites is exposed in the Strzelin II and Mikoszów quarries.

The Strzelin composite intrusion is a stock-type body, with a thick, flat apophysis and numerous dykes branching off (Oberc-Dziedzic, 1991, 1999). The roof and wall contacts of the granites with the metamorphic envelope composed of the Stachów Complex, i.e. the dark paragneisses, biotite-amphibole schists and $\sim 500$ Ma orthogneisses, are sharp and discordant. The main foliation $\mathrm{S}_{2}$ of the metamorphic rocks generally dips to the NW and SW at moderate angles, the mineral lineation plunges to the NE and SW. Adjacent to the contact with the granites, the foliation becomes steeper, nearly vertical and, locally, bent (Oberc-Dziedzic, 2007). Contact metamorphic effects are faint and limited to textural changes, such as removal of undulose extinction, straightening of grain boundaries and increase in size of quartz grains. The contact mineral changes in gneisses are also indicated by pinite pseudomorphs after cordierite.

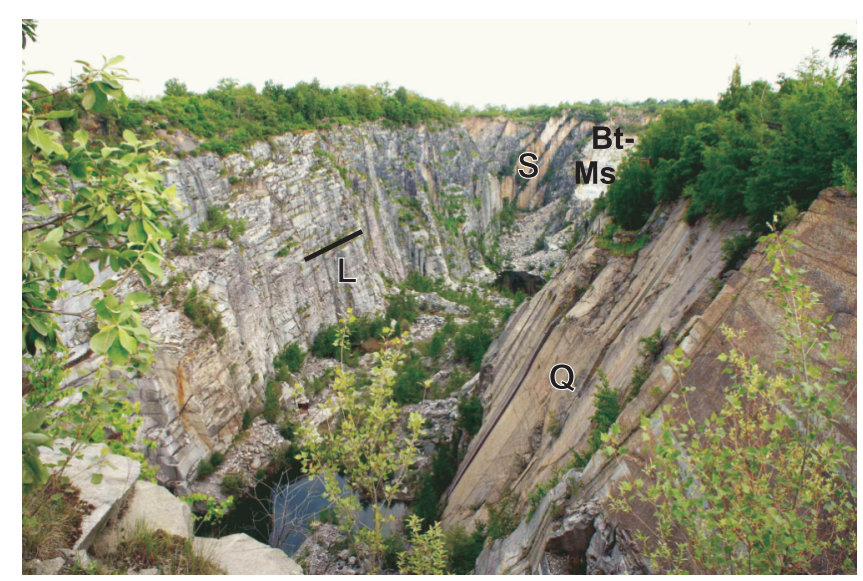

Fig. 2. The Strzelin I Quarry, view from the south-east

The quarry is $\sim 600 \mathrm{~m}$ long, $200 \mathrm{~m}$ wide and $120 \mathrm{~m}$ deep; Q, S, L joints (symbols after Cloos, 1921, 1922); Bt-Ms - biotite-muscovite granite

The southern part of the Strzelin intrusion, about $200 \mathrm{~m}$ thick (Fig. 3), is composed of the pale grey medium-grained biotite granite. The rock shows an indistinct E-W to ENE-WSW trending, subhorizontal magmatic lineation (Cloos, 1921, 1922; Oberc, 1966; Bereś, 1969). The southern contact of the medium-grained granite with the country rocks is not exposed, but numerous xenoliths of dark and pale gneiss, often surrounded by leucogranite, indicate its apparent proximity. Tonalite- and double microgranular enclaves (enclave within enclave; Didier, 1973; Lorenc, 1984) are scarce. Xenoliths of pale, very finegrained granite (Fig. 3) are interpreted as inclusions of early
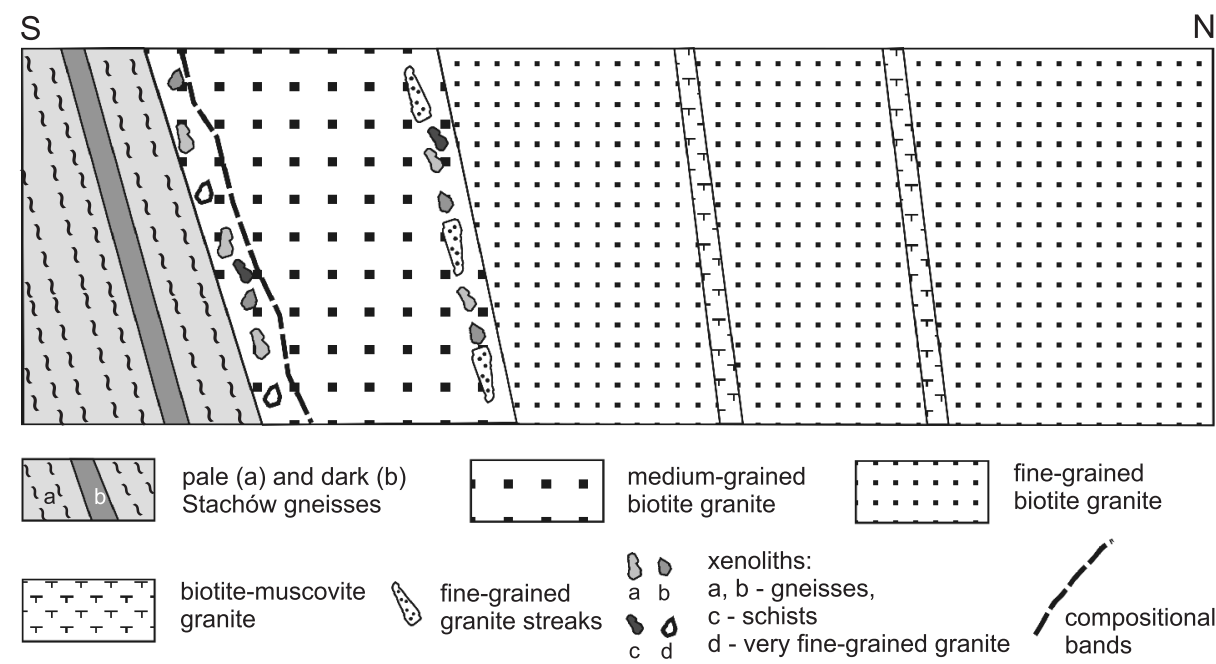

Fig. 3. Schematic cross-section through the Strzelin intrusion

The length of cross-section is ca. $700 \mathrm{~m}$

\footnotetext{
1 Turniak et al. (2006) also dated, using the same method, the Gessiniec tonalites, assigned to the 3rd stage of plutonic activity in the Strzelin Massif and obtained an age of $291 \pm 5.5 \mathrm{Ma}$. Unfortunately, this date was unintentionally not cited in our previous paper on the Gęsiniec intrusion (Oberc-Dziedzic and Kryza, 2012).
} 
crystallised margin of the medium-grained biotite granite disrupted by fresh magma injections.

Near the southern contact of the granite with the country rocks, a tens-of-metres wide zone of the medium-grained biotite granite contains centimetre- to decimeter-scale parallel fine-grained and medium-grained bands (Fig. 3) that define a generally E-W oriented steep magmatic foliation (compositional banding). The bands have been deformed into open and tight folds. Both types of bands show a faint magmatic lineation. Xenoliths enclosed in the banded zone have been wrapped by several compositional layers of the granite.

The northern part of the Strzelin intrusion is composed of fine-grained biotite granite (Fig. 3), a grey rock, usually with a characteristic bluish tint. This granite seems to be homogeneous but its particular parts show subtle but easily visible differences in colour, grain-size and proportions of the main minerals. The fine-grained granite shows an E-W to ENE-WSW oriented, subhorizontal magmatic lineation.

The poorly defined boundary between the medium-grained and the fine-grained biotite granites generally trends $E-W$ to ESE-WNW and dips steeply to the north (Bereś, 1969; Morawski and Kościówko, 1975). Close to the boundary, streaks and lenses of the fine-grained biotite granite, appear within the medium-grained granite whereas the fine-grained granite contains relatively abundant xenoliths of country rocks and schlieren originated by disaggregation of xenoliths. Several tens of metres away from the contact, xenoliths vanish and the finegrained granite becomes monotonous and contains only sparse dark enclaves, 1-3 centimetres in size, or rhythmic layering (Barrière, 1981).

The gradational contact between the medium- and the fine-grained biotite granites could be explained as a result of reworking of the older medium-grained granite by the younger fine-grained granite magma.

Both the medium- and fine-grained biotite granites are cut by steep, E-W trending dykes, several metres to tens of centimetres thick, of the leucocratic fine-grained, biotite-muscovite granite (Fig. 3). Some dykes show clearly visible lineation and late magmatic foliation, oblique to dyke boundaries, both defining S-C structures. In the NE part of the Strzelin I Quarry, the biotite-muscovite granite forms a sort of neck, several metres in diameter, surrounded by the fine-grained biotite granite. The contacts between the biotite granites and the biotite-muscovite granite are usually sharp although, locally, gradual transitions can be observed.

All types of the granites are cut by rare, thin aplite dykes. These dykes mainly follow the $Q$ joints, perpendicular to the lineation (Cloos, 1921, 1922), striking NNW to N and dipping $55-70^{\circ}$ to WWS to W. Along the $Q$ joints, pervasive hydrothermal alteration of the granites is observed (Ciesielczuk and Janeczek, 2004; Ciesielczuk, 2007). The second system of the longitudinal $S$ joints, parallel to lineation, is broadly vertical and WSW-ENE oriented, while the third $L$ joint system is roughly horizontal (Fig. 2).

\section{MATERIAL AND METHODS}

The Strzelin intrusion has been studied by the present authors for many years. The samples, field observations and photographs gathered during this long time document the petrographic variation and tectonics of the intrusion exposed at different phases of extensive granite exploitation. The majority of the samples analysed come from the Strzelin I and, sub- ordinately, from the Strzelin II quarries (Fig. 1D). Each sample is labeled by its number while the variety of granite it belongs to is indicated in the table headings and diagrams.

The petrographic characterization is based on more than 100 thin sections examined under the polarizing microscope. The chemical compositions of the rock-forming and accessory minerals, i.e. micas, feldspars and garnets, in seven representative specimens of the various granites have been analysed with the CAMECA SX 100 instrument at the Inter-Institute AnaIytical Complex for Minerals and Synthetic Substances, Electron Microprobe Laboratory, Faculty of Geology, the University of Warsaw. The analytical conditions were: acceleration voltage $15 \mathrm{kV}$, beam current $10 \mathrm{nA}$ for plagioclase and mica, and $20 \mathrm{nA}$ for other minerals, and counting time $20 \mathrm{~s}$. The raw data were processed with the PAP software supplied by CAMECA. Mineral abbreviations used in this study are from Whitney and Evans (2010).

Seven bulk-rock samples were analysed in the ACME AnaIytical Laboratories Ltd, Canada, and in the ALS Canada, for major, trace and rare earth elements, using combined ICP-OES and ICP-MS techniques. One sample of the fine-grained granite (STIN 3) and two samples of the biotite-muscovite granite (STIN 1, STIN 2) from the Strzelin I Quarry, those studied earlier for Rb-Sr isotopes (Oberc-Dziedzic et al., 1996), have been analysed by one of the authors (CP) for Sm-Nd isotopes, following the procedure described by Pin and Santos Zalduegui (1997). The initial ${ }^{143} \mathrm{Nd} /{ }^{144} \mathrm{Nd}$ ratios are expressed as $\varepsilon \mathrm{Nd}_{\mathrm{i}} \mathrm{val}-$ ues, corrected for in situ decay of ${ }^{147} \mathrm{Sm}$, assuming an age of $300 \mathrm{Ma}$ for the granites, and model ages are calculated relative to the depleted mantle model of de Paolo (1981a, b).

One sample of the medium-grained $(300 \mathrm{~V})$ and two samples of the fine-grained biotite granite (300 IV, $300 \mathrm{VI})$ have been selected for SHRIMP zircon dating. Details of the SHRIMP analytical procedures are given in the geochronology section below.

Documentation of the research (samples, thin sections, complete data sets of the whole-rock isotopic, EMP and SHRIMP analyses, and the photo documentation) are available from the first two authors.

\section{PETROGRAPHY}

The medium-grained biotite granite (shortly mediumgrained granite) is a pale grey rock composed of quartz, microcline, plagioclase and biotite. The average grain size is 2-5 mm, but, generally, microcline grains are larger than plagioclase. A faint lineation is defined by the alignment of feldspars and slightly elongated quartz aggregates. The medium-grained granite contains abundant myrmekite.

The banded medium-grained granite near the contact with the country rocks comprises bands of different grain size: fine-grained bands (grains of $0.5-2.0 \mathrm{~mm}$ in size) and medium-grained bands in which plagioclase is up to $3.0 \mathrm{~mm}$ and microcline up to $5.0 \mathrm{~mm}$ large. Both types of bands show an indistinct lineation defined by the roughly parallel distribution of larger feldspar grains in the medium-grained bands, and of biotite plates in the fine-grained bands. In the banded mediumgrained granite, myrmekite is rare.

The grey, very fine-grained granite, only present as xenoliths believed to represent dispersed fragments of marginal facies (sample 6902 IV), shows a porphyritic texture: the grain size in the matrix is $\sim 0.5 \mathrm{~mm}$, plagioclase and microcline phenocrysts reach $\sim 1.5 \mathrm{~mm}$. This granite abounds in myrmekite, as in the medium-grained granite. 
The fine-grained biotite granite (in short, fine-grained granite) is a grey rock, with a bluish tint. It shows subtle differences in colour, texture and the proportions of the main components: quartz, microcline, plagioclase and biotite. The size of most plagioclase grains is $0.5-1.5 \mathrm{~mm}$. Microcline and biotite grains are smaller than plagioclase. Occasionally, plagioclase and biotite form clusters composed of several grains. Parallel arrangement of plagioclase grains defines a lineation. Myrmekite is rare.

The fine-grained biotite-muscovite granite (in short, biotite-muscovite granite) is a pale rock composed of quartz, microcline, plagioclase, biotite, muscovite, euhedral pinite pseudomorphs after cordierite, and rare garnet. The grain size is $0.5-2.0 \mathrm{~mm}$. Minerals are randomly distributed or parallel-aligned. Micrographic intergrowths of microcline with quartz, and myrmekite, are scarce.

Aplite is mesoscopically similar to the biotite-muscovite granite. However, the grain size is below $0.5 \mathrm{~mm}$ and all minerals are anhedral in habit. The mineral composition of the aplite is similar to that of the biotite-muscovite granite, but pinite pseudomorphs are absent.

\section{COMPARISON OF ROCK-FORMING} MINERALS

K-feldspar. In all varieties of the Strzelin granites, K-feldspar is microcline with characteristic tartan twinning, and is always anhedral. In the medium-grained granite, K-feldspar is usually more frequent than in the fine-grained granite and it forms larger grains. In the medium-grained granite and in the very fine-grained granite of the xenoliths (sample 6902 IV), microcline shows evidence of a two-stage history, as documented by rounded or irregular cores mantled by microcline of different optical orientation (Fig. 4A). Microcline of the medium-grained granite contains small inclusions of zoned plagioclase. In the very fine-grained granite of the xenoliths, microcline contains drop-like inclusions forming a ring parallel to the grain border (Fig. 4A). Drop-like quartz inclusions are present also in microcline of the adjacent medium-grained granite, but they seldom form rings. The two-stage history and other features of the microcline crystals from the mediumgrained granite and very fine-grained granite preserved as xenoliths of dismembered margins suggest a close relationship of these two rocks, contrasting with the fine-grained biotite granite. The anorthite (An) component in microcline of all granite varieties is very low, usually about $0-1 \%$, whereas the albite $(A b)$ component varies between $2-11 \%$. The average value of the celsian (Cls) content is relatively high in the medium-grained granite $(0.66 \%)$ and lower in the fine-grained granite $(0.40 \%)$, biotite-muscovite granite $(0.3 \%)$, and aplite $(0.15 \%)$.

Plagioclase. In the medium-grained granite, plagioclase forms two types of grain. The first type is represented by tabular or slightly rounded, untwined grains, with clear rims and etched internal parts. They contain inclusions of chlorite, sericite, epidote and K-feldspar. These plagioclases show 14-16\% An in the core, $20-22 \%$ An in the inner part of the rim, and $8-9 \%$ An in its outer part (Appendix $\left.1^{*}\right)$. The second type of plagioclase is represented by clear, twinned rectangular crystals, with cores characterized by irregular compositions and with oscillatory rims. They contain $29-32 \%$ An in the core and $14-26 \%$ An
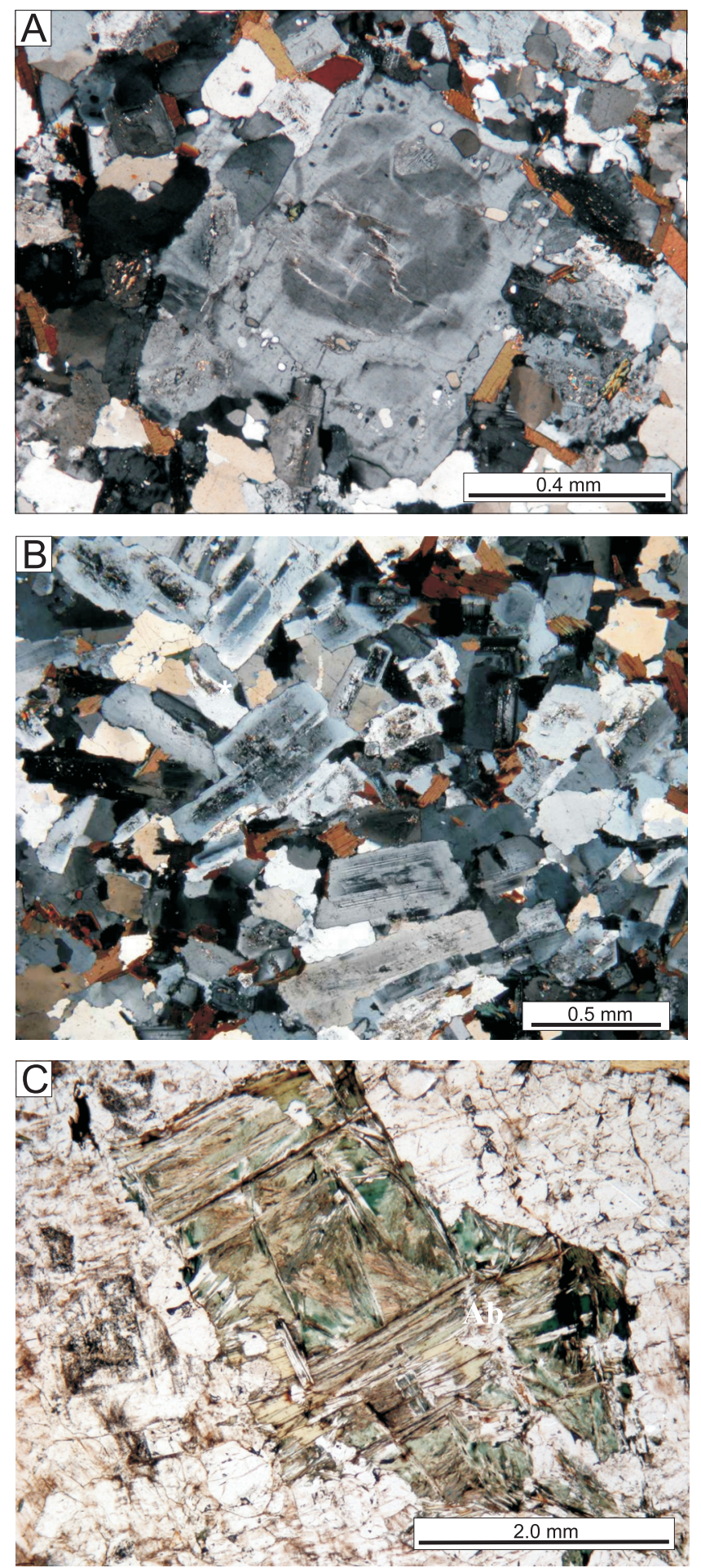

Fig. 4. Mineralogy and textures of the Strzelin granites

A-microcline (centre of photo) of the very fine-grained granite shows a rounded core while the envelope is different optical orientation; drop-like inclusions of quartz form a ring parallel to the grain border; $\mathbf{B}$ - microscopic evidence of magmatic flow in the fine-grained biotite granite: parallel and "train-like" arrangement of plagioclase, tiling and synneusis (middle part of the photo); C - euhedral pseudomorphs of pinite in the fine-grained biotite-muscovite granite

* Supplementary data associated with this article can be found, in the online version, at doi: $10.7306 / \mathrm{gq} .1083$ 


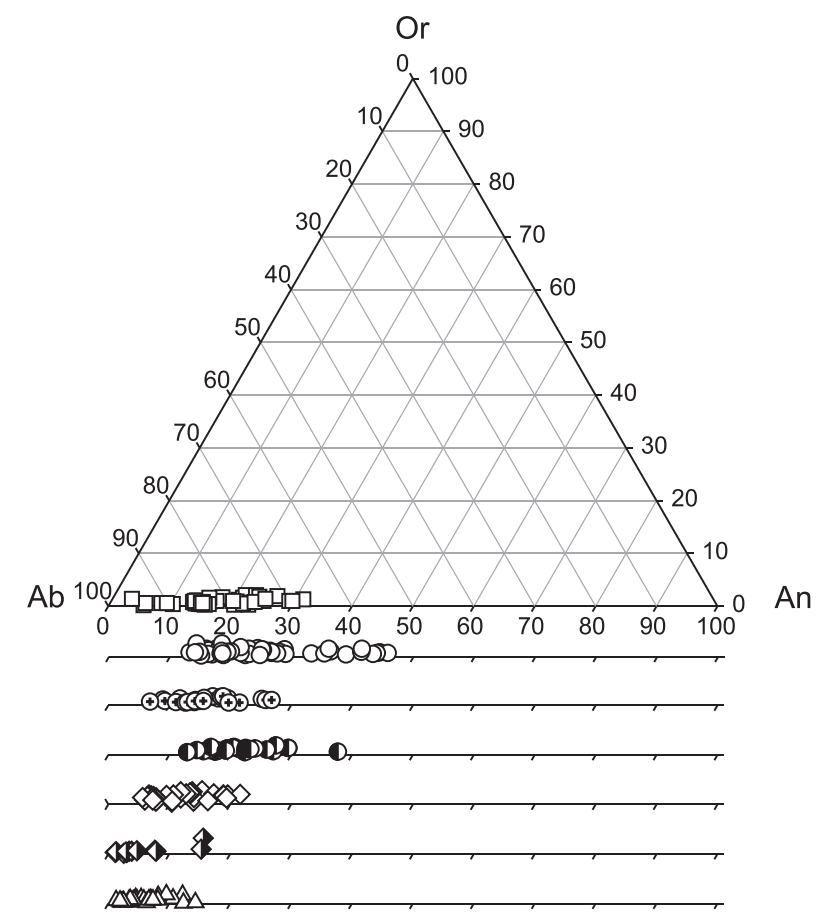

$\square$ medium-grained granite $200-2$

fine-grained granite $200-1$

( ) fine-grained granite $300 \mathrm{IV}$

D very fine-grained granite 6902 IV
$\diamond$ Bt-Ms granite $300 \mathrm{II}-1$
$\triangleleft$ Bt-Ms granite $300 \mathrm{II}-1 \mathrm{a}$
$\triangle$ aplite $300 \mathrm{l}-1$

Fig. 5. Composition of plagioclase from granites of the Strzelin intrusion

in the rim (Appendix 1). Plagioclase also forms inclusions in microcline, having $13.5-24.5 \% \mathrm{An}$ in the core and $6.0-10.5 \%$ An in the rim (Fig. 5).

In the grey, very fine-grained granite (sample 6902 IV), plagioclase forms euhedral grains with dusty, etched cores (26-37\% An) and clear rims (17-22\% An). There are also anhedral grains with 14-19\% An (Fig. 5).

In the fine-grained biotite granite, plagioclase forms tabular crystals with euhedral, etched dusty cores and subhedral rims (Fig. 4B). Some grains are composed of two crystals, stitched along their longer sides, probably due to synneusis (Vance, 1969; Stull, 1979). Such grains have their own zoning transposed along the stitch and a common rim formed after synneusis (Vernon, 2004; Fig. 4B). In spite of similar appearance, the plagioclase grains differ in An contents in the cores and rims. In some grains, the An content in the cores is high, $35-45 \%$. The clear rims display $13-33 \%$ An (Fig. 5 and Appendix 1). Other grains contain up to $26 \%$ An in the cores and $13-18 \%$ An in the rims and, occasionally, only $6.5 \%$ in oscillatory rims (Fig. 5 and Appendix 1). Such grains either coexist with the former (35-45\% An) or are the only type of plagioclase in the rock. The coexistence of the two types of plagioclase may be interpreted as evidence of magma differentiation before its emplacement, or magma mixing. Plagioclase rims on $\mathrm{Kfs}$ grains have $12.5-14.5 \% \mathrm{An}$.

In the biotite-muscovite granite, plagioclase has tabular forms, with euhedral, etched, dusty cores and euhedral, wide and clear rims. Plagioclase cores (18-21\% An) are surrounded by rims that are normally $(4.5-16.5 \%$ An) or oscillatory (4.5-7.5\% An) zoned (Fig. 5 and Appendix 1). Plagioclase inclusions in K-feldspar show $19 \% \mathrm{An}$ in cores and $7 \% \mathrm{An}$ in rims.
The aplites contain two varieties of plagioclase: euhedral with dusty core, and subhedral, usually clear, with polysynthetic twinning. In a complex, euhedral crystal, the dusty core containing $12-14 \%$ An is surrounded by a thin, clear, internal rim, composed of $10-11 \%$ An plagioclase, and a wider external rim, with $5.5-6.0 \%$ An. In other euhedral grains, we measured 6-9\% An in the cores and $2.5-5.0 \% \mathrm{An}$ in the rims. Subhedral, twinned grains are reverse zoned, with $2 \% \mathrm{An}$ in the cores and about 4\% An in the rims (Fig. 5 and Appendix 1).

Biotite. On diagrams $\mathrm{Mg} /(\mathrm{Mg}+\mathrm{Fe}+\mathrm{Mn})$ vs. $\mathrm{Al}^{\mathrm{Vl}}$ and $\mathrm{Mg} /(\mathrm{Mg}+\mathrm{Fe}+\mathrm{Mn}) \mathrm{vs}$. Ti, biotite compositions form two arrays; one for biotite from the fine-grained granite, and the second array for biotites from the remaining granite varieties (Fig. 6A, B and Appendix 2).

The $\mathrm{Mg} /(\mathrm{Mg}+\mathrm{Fe}+\mathrm{Mn})$ atomic ratios of $\sim 0.26$ in biotite from the fine-grained granite are higher (Fig. 6A, B) than in the medium-grained $(\sim 0.17)$ and very fine-grained variety $(\sim 0.15)$, as well as in the biotite-muscovite granite $(0.14-0.24)$ and aplite (0.17-0.22). On the $\mathrm{Al}^{\mathrm{tot}}$ vs. Ti diagram (Fig. 6C and Appendix 2), biotite compositions also form two clusters. The first comprises biotite from the biotite granites (medium- and finegrained, and the very fine-grained marginal facies). In these biotites, the $\mathrm{Ti}$ content is distinctly higher $(0.30-0.53$, average $\sim 0.38 \mathrm{apfu}$ ) and $\mathrm{Al}^{\mathrm{tot}}$ is lower (average $\sim 3.13 \mathrm{apfu}$ ) than in the second cluster from the biotite-muscovite granite (average: $\mathrm{Ti}$ $\sim 0.20$ apfu; $\mathrm{Al}^{\text {tot }} \sim 3.70 \mathrm{apfu}$ ) and the aplite (average $\mathrm{Ti}$ $\sim 0.26$ apfu; $\mathrm{Al}^{\text {tot }} 3.52$ apfu; Fig. $6 \mathrm{C}$ and Appendix 2). Similarly as $\mathrm{Al}^{\text {tot }}, \mathrm{Al}^{\mathrm{Vl}}$ is lower in biotites from the biotite granites (average $\sim 0.53 \mathrm{apfu}$ ) than in biotites from the biotite-muscovite granite (average $\sim 0.95 \mathrm{apfu}$ ) and from the aplite (average $0.80 \mathrm{apfu}$; Fig. 6A and Appendix 2).

Garnet was found only in the biotite-muscovite granite and in the aplite. In the biotite-muscovite granite, it occurs within pinite pseudomorphs after cordierite or close to them. It forms sparse, euhedral crystals, $0.1-0.2 \mathrm{~mm}$ in size, without compositional zoning or inclusions. It contains: spessartine $66.3-67.7 \%$, almandine $28.8-30.0 \%$, and only small amounts of grossular + andradite $(2.3-3.3 \%)$ and pyrope $(0.6-1.1 \%)$ (Appendix 3).

In the aplite, garnet forms small, $0.1 \mathrm{~mm}$ in size, grains associated with biotite flakes. It contains $57.4-60.9 \%$ almandine, $36.6-40.0 \%$ spessartine, $1.9-2.8 \%$ pyrope and $0.3-0.5 \%$ grossular + andradite (Appendix 3 ). It does not show any compositional zoning.

Comparison of the garnet composition in the biotite-muscovite granite with that from the aplite reveals significant differences suggesting different parent magmas of the two rocks.

Pinite occurs only in the biotite-muscovite granite. Usually, it contains aggregates of tiny biotite, muscovite and chlorite, arranged parallel or fan-like. Euhedral pseudomorphs of pinite occur in rare coarse-grained bands, enriched in perthitic microcline. Such pseudomorphs of rectangular shape, up to $2.0 \mathrm{x}$ $1.5 \mathrm{~mm}$ in size (Fig. 4C), are composed of green biotite in the outer part and fans of tiny plates of muscovite, both biotite and muscovite containing very little Ti (below 0.02 apfu). Garnet, andalusite, zircon, monazite and xenotime form inclusions in pinite pseudomorphs. The pseudomorphs are, in places, entirely replaced by muscovite.

\section{BULK-ROCK CHEMISTRY}

\section{MAJOR ELEMENTS}

The three main types of rocks in the Strzelin intrusion, the medium-grained granite, the fine-grained granite, and the bio- 
A

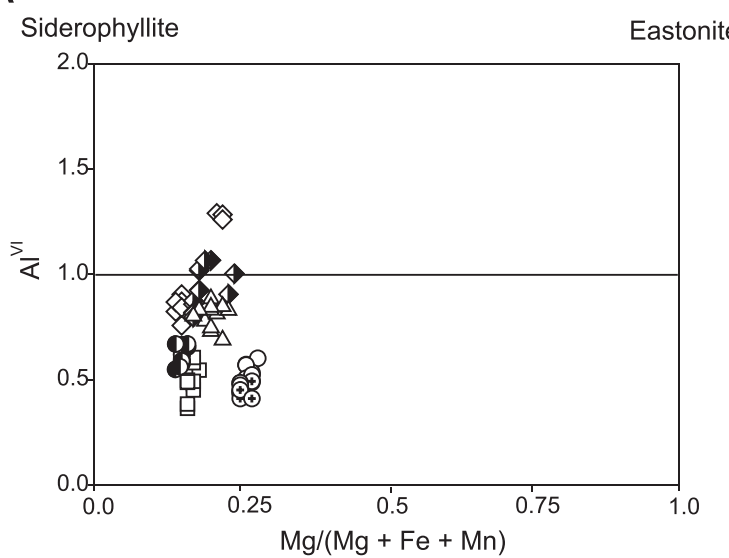

B

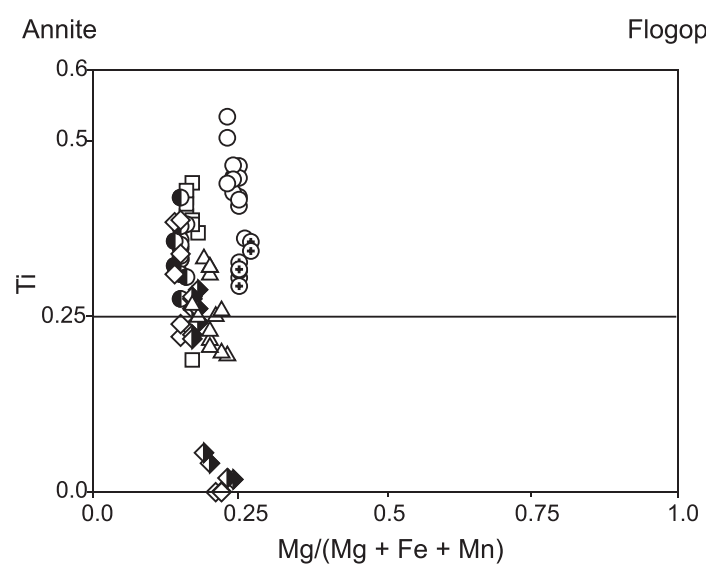

C

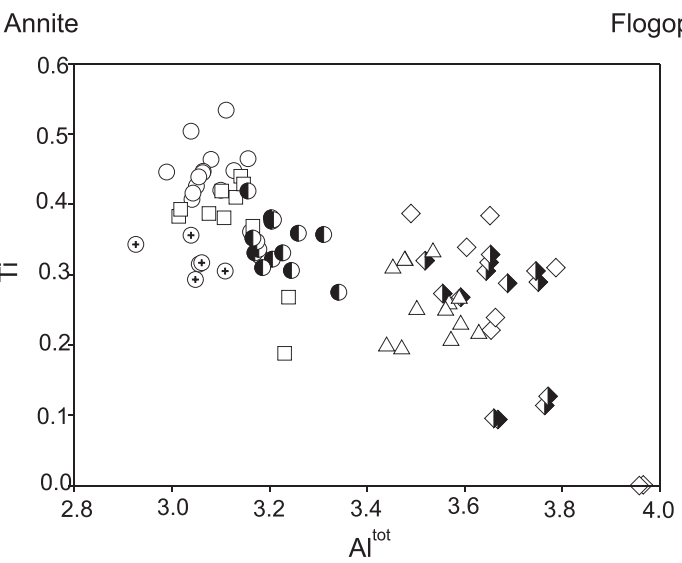

Fig. 6. Composition of biotite from granites of the Strzelin intrusion plotted on diagrams

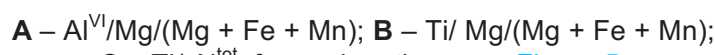
C $-\mathrm{Ti} / \mathrm{Al}^{\text {tot }}$; for explanations see Figure 5

tite-muscovite granite, differ considerably in major element contents (Appendix 4). The fine-grained granite contains less $\mathrm{SiO}_{2}$ and $\mathrm{K}_{2} \mathrm{O}(72.0-73.0$ wt. $\%$ and $3.57-3.99$ wt.\%) than the medium-grained granite (73.9-74.7 wt. $\%$ and $4.66-5.13$ wt. $\%)$ and biotite-muscovite granite (76.0-76.5 wt.\% and 4.51-5.76 wt.\%), but it is richer in $\mathrm{Al}_{2} \mathrm{O}_{3}, \mathrm{Fe}_{2} \mathrm{O}_{3}, \mathrm{MgO}, \mathrm{CaO}$ and $\mathrm{TiO}_{2}$. These chemical differences are reflected in the rock-forming mineral contents and in mineral chemistry. Based on the classification of Frost et
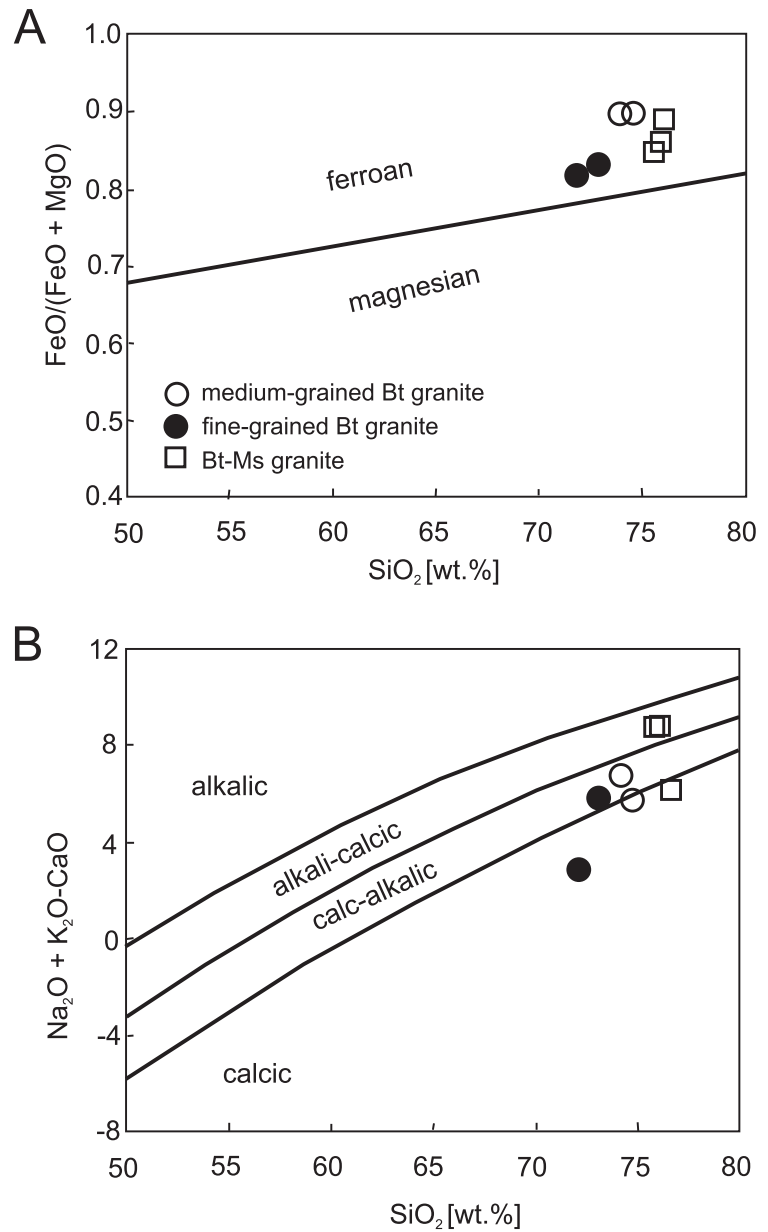

Fig. 7. Classification diagrams (Frost et al., 2001) for granites of the Strzelin intrusion

$$
\begin{gathered}
\mathbf{A}-\mathrm{FeO} /(\mathrm{FeO}+\mathrm{MgO}) \text { vs } \mathrm{SiO}_{2} \\
\mathbf{B}-\mathrm{Na}_{2} \mathrm{O}+\mathrm{K}_{2} \mathrm{O}-\mathrm{CaO} \text { vs } \mathrm{SiO}_{2}
\end{gathered}
$$

al. (2001), the rocks are ferroan (Fig. 7A) calcic to calc-alkalic and alkali-calcic (Fig. 7B). All the granites are potassium-rich and peraluminous to metaluminous, with $\mathrm{A} / \mathrm{CNK}$ of $1.0-1.1$ in the biotite-muscovite granite, 1.0 in the medium-grained granite, and 0.9-1.0 in the fine-grained granite (Appendix 4).

\section{TRACE ELEMENTS}

The two types of biotite granite are richer in $\mathrm{Ba}$ (604-1100 ppm), Sr (140-184 ppm) and $\mathrm{Zr}$ (167-279 ppm) but contain less $\mathrm{Rb}(128-149 \mathrm{ppm})$ and $\mathrm{U}(3.1-5.3 \mathrm{ppm})$ than the biotite-muscovite granite (Ba: 96-172, Sr: 21-35, Zr: 58-63, Rb: 237-302, U: 9.4-14.5 ppm; Appendix 4). The multi-element diagrams of trace element concentrations, normalized to chondrite, for the biotite- and biotite-muscovite granites are characterized by strong $\mathrm{Nb}, \mathrm{Sr}, \mathrm{P}$ and Ti negative anomalies (Fig. 8A, C). These negative anomalies may reflect fractionation of plagioclase, apatite, and Fe-Ti oxides during earlier stages of magma evolution, but they are also likely to be, at least in part, inherited from the source materials, because typical continental crust materials show depletion of these elements relative to the other incompatible elements such as the REE (Taylor and McLennan, 1985). 

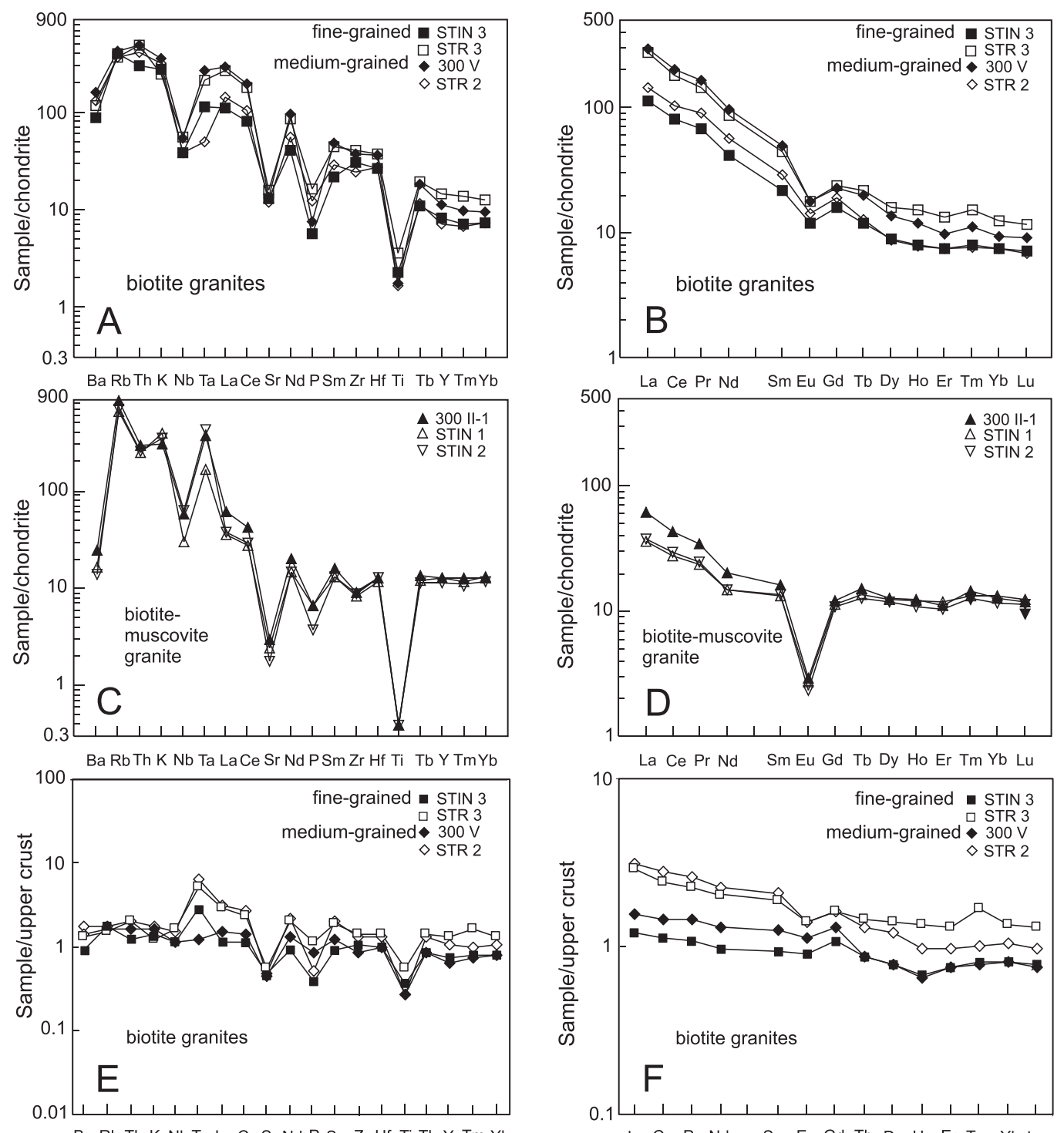

Ba Rb Th K NbTa La CeSrNd P Sm Zr Hf Ti Tb Y Tm Y
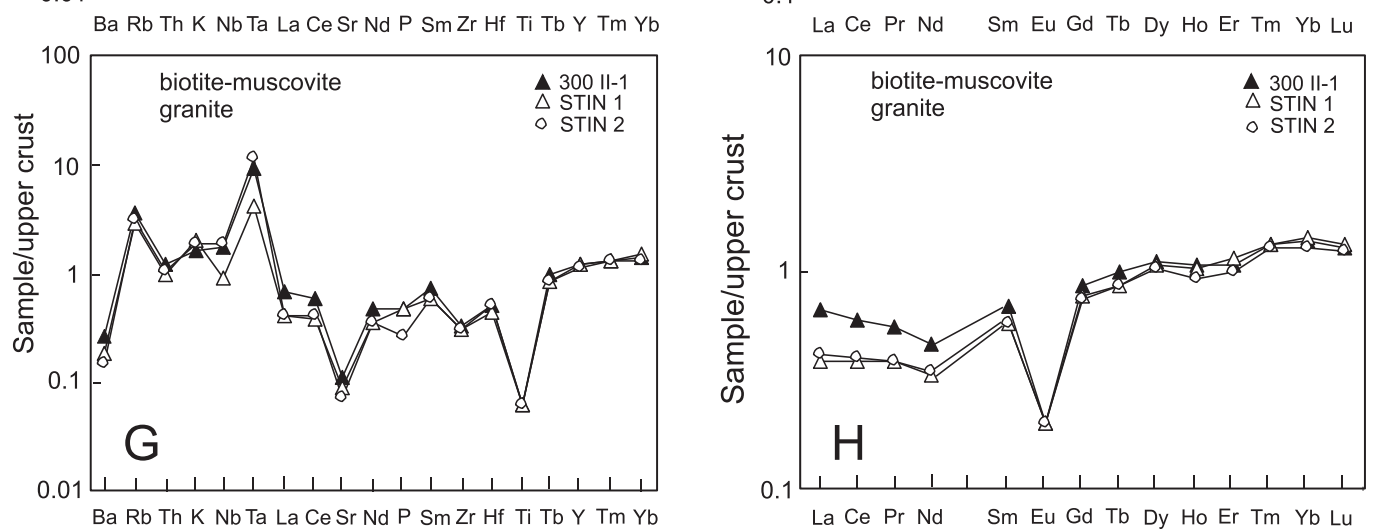

Fig. 8. Multi-element and REE diagrams for granites of the Strzelin intrusion

Chondrite normalized: A, C - multi-element diagrams (normalization values of Thompson, 1982); B, D - REE plots (normalization values of Nakamura, 1974, with additions from Haskin et al., 1968); upper-crust normalized (normalization values of Rudnick and Gao, 2005): E, G - multi-element diagrams; F, H - REE plots 
In both types of biotite granite, the total REE contents (158-377 ppm) are much higher than in the biotite-muscovite granite (66-94 ppm; Appendix 4). The chondrite-normalized REE patterns of the biotite granites (Fig. 8B) display distinct, steeply decreasing LREE and HREE branches, and negative anomalies of Eu/Eu*, between 0.54-0.64 (Appendix 4). The $(\mathrm{La} / \mathrm{Yb}) \mathrm{N}$ ratios range from 15.19 to 30.82 . The chondrite-normalized REE patterns of the biotite-muscovite granite show a slight tetrad effect (Fig. 8D). They are characterized by distinct, steeply decreasing LREE and flat HREE, and even deeper negative anomaly of Eu/Eu*, between 0.18-0.22 (Appendix 4). The $(\mathrm{La} / \mathrm{Yb}) \mathrm{N}$ ratios are between 2.72 and 4.87 .

Trace element abundances in the medium-grained and fine-grained biotite granites are close to those in the upper continental crust (Rudnick and Gao, 2005). Depletion of Sr, P and $\mathrm{Ti}$ (Fig. 8E) is also typical of continental crust materials. There is no $\mathrm{Nb}$ anomaly in this diagram. The REE diagram (Fig. 8F) shows a general correspondence to the average upper-crust composition, with the LREE slightly enriched relative to the HREE, poorly pronounced Eu anomalies and Tm enrichment in one sample of the fine-grained biotite granite.

The trace-element, diagrams normalized to upper crust, for the biotite-muscovite granite (Fig. 8G, H) show considerable differences compared to those for the biotite granites. The $\mathrm{Sr}$ and Ti negative anomalies and Ta positive anomaly are much more pronounced in the biotite-muscovite granite, but the $P$ anomaly is hardly noticeable. The REE patterns (Fig. $8 \mathrm{H}$ ) are characterized by strong depletion in LREE, especially $\mathrm{Nd}$, a strong Eu negative anomaly, and enrichment in HREE relative to LREE. The abundances of Gd, Tb, Dy, Ho and Er are close to those of upper continental crust, but $\mathrm{Tm}, \mathrm{Yb}$ and $\mathrm{Lu}$ are a little higher.

\section{Sm-Nd ISOTOPE}

The fine-grained biotite granite (STIN 3) displays a low, typically crustal ${ }^{147} \mathrm{Sm} /{ }^{144} \mathrm{Nd}$ ratio $(0.1067)$, whereas the biotitemuscovite granite (samples STIN 1 and STIN 2) has much higher ${ }^{147} \mathrm{Sm} /{ }^{144} \mathrm{Nd}(0.1715-0.1804)$ values (Appendix 5), which are interpreted to reflect the fractionation of one, or several, LREE-enriched accessory mineral(s), e.g., monazite and/or apatite, as suggested by the low contents in $\mathrm{P}_{2} \mathrm{O}_{5}$. As a result, the very old $T_{\mathrm{DM}}$ model ages (de Paolo, 1981a, b) calculated for these two samples ( 3.44 and $2.75 \mathrm{Ga}$, respectively) do not have any significance, because in these samples, the REE obviously did not follow a simple two-stage evolutionary model, with a single event of major $\mathrm{Sm} / \mathrm{Nd}$ fractionation believed to have occurred during extraction from a theoretical mantle reservoir, as implied by conventional model age calculations. Assuming common crustal $\mathrm{Sm} / \mathrm{Nd}$ ratios $\left({ }^{147} \mathrm{Sm} /{ }^{144} \mathrm{Nd}\right.$ $\sim 0.11-0.12$ ) for the pre- $0.3 \mathrm{Ga}$ crustal residence stage (that is, prior to the strong increase in $\mathrm{Sm} / \mathrm{Nd}$ due to fractionation of LREE-rich accessory phases), model ages relative to the depleted mantle in the 1.2-1.4 Ga range would be obtained. The ${ }^{143} \mathrm{Nd} /{ }^{144} \mathrm{Nd}$ isotope ratios have been corrected for in situ radioactive decay of ${ }^{147} \mathrm{Sm}$ into ${ }^{143} \mathrm{Nd}$ by using the ca. $300 \mathrm{Ma} U-\mathrm{Pb}$ zircon age measured by SHRIMP, and expressed as initial epsilon values. The $\varepsilon \mathrm{Nd}_{300}$ of the fine-grained biotite granite $(-3.8)$ reflects a magma source that was moderately enriched in LREE on a time-integrated basis. The $T_{\mathrm{DM}}$ model age of $1.1 \mathrm{Ga}$ provides an estimate of the average crustal residence age of the source materials, without any further geological significance. The two samples of biotite-muscovite granite have a dis- tinctly less radiogenic $\mathrm{Nd}$ isotope signature $\left(\varepsilon \mathrm{Nd}_{300}-5.4\right.$ and -5.7 ) that points to a geochemically more evolved source, dominated by an ancient LREE-enriched contribution.

\section{SHRIMP ZIRCON STUDY}

SAMPLING AND METHODS

Three samples, one medium-grained $(300 \mathrm{~V})$ and two fine-grained granites (300 IV, $300 \mathrm{VI}$ ) from the Strzelin I and II quarries (Fig. 1D) have been selected for SHRIMP zircon investigations. Sample $300 \mathrm{~V}$ represents typical medium-grained granite described in the Petrography section. Samples 300 IV and $300 \mathrm{VI}$ differ in colour (grey with a bluish tint, and grey, respectively) and grain size $(0.5-1.5 \mathrm{~mm}$ and $1.5-2.0 \mathrm{~mm}$, respectively). In sample $300 \mathrm{VI}$, microcline is more abundant and biotite is less chloritized than in sample $300 \mathrm{IV}$.

The samples selected for SHRIMP analysis, each ca. $3-5 \mathrm{~kg}$ in weight, were crushed and the heavy mineral fraction $(0.06-0.25 \mathrm{~mm})$ separated using a standard procedure with heavy liquids and magnetic separation. Zircons were handpicked under a microscope, mounted in epoxy and polished. Transmitted and reflected light photomicrographs were made, along with $\mathrm{CL}$ images, in order to select grains and choose sites for analysis. The Sensitive High Resolution Ion Microprobe (SHRIMP II) was used to analyse the zircons in the samples selected. Samples $300 \mathrm{~V}$ and $300 \mathrm{IV}$ were analysed at the Centre of Isotopic Research (CIR) at the All-Russian Geological Research Institute (VSEGEI) in St. Petersburg. Sample $300 \mathrm{VI}$ was analysed in the Beijing SHRIMP Center, Chinese Academy of Geological Sciences.

In both laboratories, the analytical procedures and conditions were very similar. $\mathrm{U}-\mathrm{Pb}$ analyses were performed by using a secondary electron multiplier in peak-jumping mode following the procedure described in Williams (1998) and Larionov et al. (2004). A primary beam of molecular oxygen was employed to bombard zircon in order to sputter secondary ions. The elliptical analytical spots had a size of ca. $25 \times 30 \mu \mathrm{m}$, and the corresponding ion current was ca. $4 \mathrm{nA}$. The sputtered secondary ions were extracted at $10 \mathrm{kV}$. The $80 \mu \mathrm{m}$ wide slit of the secondary ion source, in combination with a $100 \mu \mathrm{m}$ multiplier slit, allowed mass-resolution of $\mathrm{M} / \Delta \mathrm{M}>5000$ ( $1 \%$ valley) so that all the possible isobaric interferences were resolved. One(VSEGEI) or two-minute (Beijing) rastering was employed before each analysis in order to remove the gold coating and any possible surface common $\mathrm{Pb}$ contamination.

The following ion species were measured in sequence: ${ }^{196}\left(\mathrm{Zr}_{2} \mathrm{O}\right)-{ }^{204} \mathrm{~Pb}-$ background (ca. 204 AMU) $-{ }^{206} \mathrm{~Pb}-{ }^{207} \mathrm{~Pb}-$ ${ }^{208} \mathrm{~Pb}^{238} \mathrm{U}-{ }^{248} \mathrm{ThO}^{254} \mathrm{UO}$ with integration time ranging from 2 to 20 seconds. Four cycles for each spot analysed were acquired. Each fifth measurement was carried out on the zircon $\mathrm{Pb} / \mathrm{U}$ standard TEMORA 1 (Black et al., 2003) with an accepted ${ }^{206} \mathrm{~Pb} /{ }^{238} \mathrm{U}$ age of $416.75 \pm 0.24 \mathrm{Ma}$. The 91500 zircon with a $U$ concentration of $81.2 \mathrm{ppm}$ and a ${ }^{206} \mathrm{~Pb} /{ }^{238} \mathrm{U}$ age of $1062.4 \pm$ $0.4 \mathrm{Ma}$ (Wiedenbeck et al., 1995) was applied as a "U-concentration" standard.

The collected results were then processed with the SQUID v1.12 (Ludwig, 2005a) and ISOPLOT/Ex 3.22 (Ludwig, 2005b) software, using the decay constants of Steiger and Jäger (1977). The common lead correction was done using measured ${ }^{204} \mathrm{~Pb}$ according to the model of Stacey and Kramers (1975). The results of the zircon analyses are shown in Appendices 6-8 


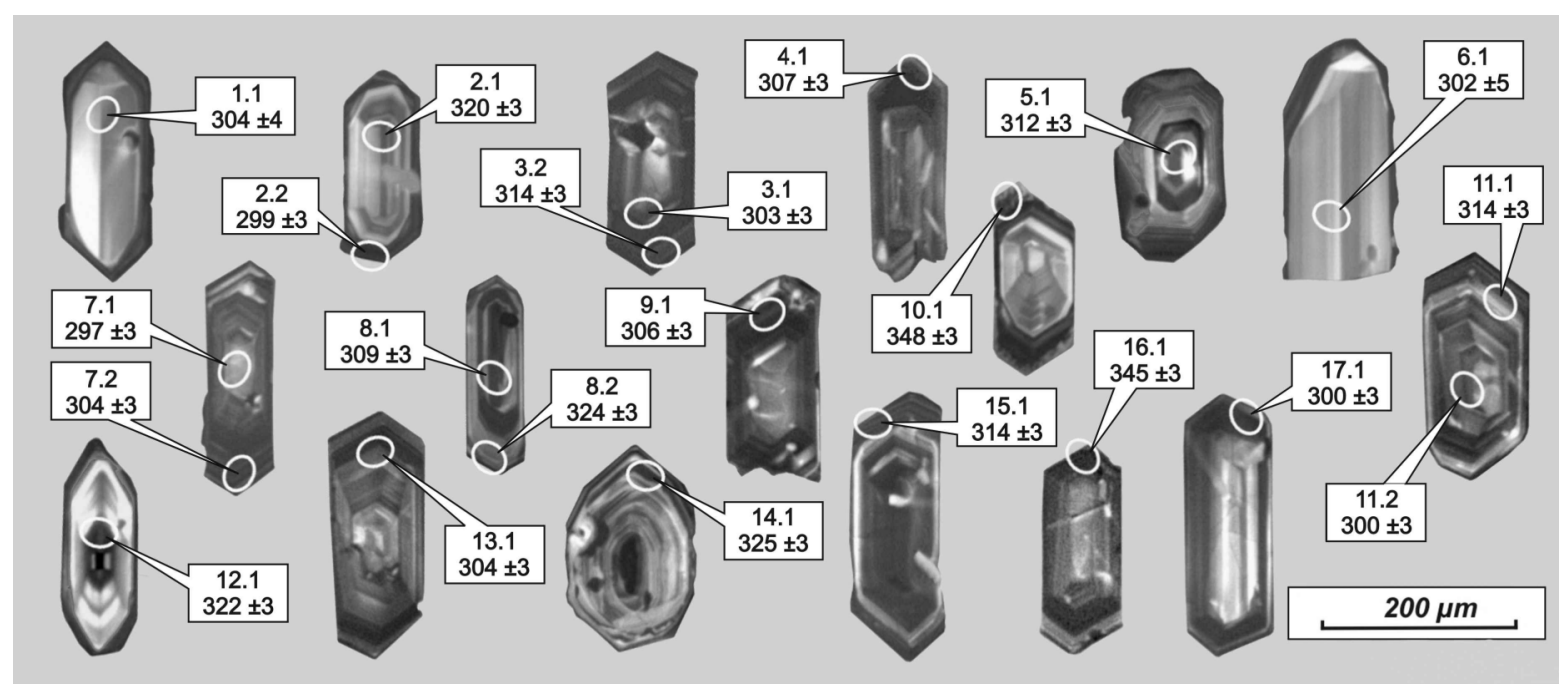

Fig. 9. CL images of selected zircons from the medium-grained Bt granite (sample $300 \mathrm{~V}$ )

and Figures 9-14. Conventionally, the ages given in the text, if not additionally specified, are ${ }^{207} \mathrm{~Pb} /{ }^{206} \mathrm{~Pb}$ ages for zircons older than $650 \mathrm{Ma}$, and ${ }^{206} \mathrm{~Pb} /{ }^{238} \mathrm{U}$ ages for zircons younger than $650 \mathrm{Ma}$. The errors in the text and tables are given at the $1 \sigma$ level for individual points, and at $2 \sigma$ level in Concordia diagrams and for average Concordia ages.

\section{SAMPLE $300 \mathrm{~V}$}

MEDIUM-GRAINED GRANITE

Zircon characteristics. Morphologically, the majority of zircons are fairly homogenous: mostly euhedral, normal- to longprismatic grains, with shallow pyramid dominant forms. They are transparent, colourless and clear, some with needle-like or oval inclusions. A very few grains are more irregular, subhedral or oval in shape, locally broken, likely during crushing and separation.

In the CL images (Fig. 9), the zircons reveal various internal structures: some are more or less distinctly zoned, typically with generally CL-darker internal parts, occasionally with badlyshaped core-like structures in the centre of the grains (e.g., grains 7.1 and 8.1), others display only irregular "ghost" zoning. A few grains have distinct CL-dark rims. Rare grains of irregular or oval shape are also CL-dark.

Chemical and isotopic characteristics are generally constant in the grains analysed (Appendix 6). The ${ }^{206} \mathrm{~Pb}_{\mathrm{c}}$ concentrations are generally low, reaching elevated values up to $\sim 1-2 \%$ in four points only (maximum value 2.2 ). The $U$ and Th contents vary between 176 and 4231 ppm, and Th 144 and $2324 \mathrm{ppm}$, respectively. The ${ }^{232} \mathrm{Th} /{ }^{238} \mathrm{U}$ ratios range from 0.11 to 1.13. All these chemical and isotopic parameters display similar ranges in all age groups (see below).

The generally homogeneous "magmatic" habit of the majority of zircons, as well as their rather constant chemical and isotopic characteristics, indicate that they were formed, in general, during magmatic processes, however, the observed variations of the internal structures, and to some extent of some chemical features, suggest a possible complex crystallisation during changing physical/chemical conditions.

SHRIMP ages. Twenty-two analytical points have been measured in 17 grains (Appendix 6). All the data points have rel- atively low discordance $D\left(D=\left[\left(\right.\right.\right.$ age $\left.{ }^{207} \mathrm{~Pb} /{ }^{206} \mathrm{~Pb}\right) /($ age $\left.\left.{ }^{206} \mathrm{~Pb} /{ }^{238} \mathrm{U} /\right)-1\right] \times 100$ ) between -6 and $+6 \%$. The ${ }^{206} \mathrm{~Pb} /{ }^{238} \mathrm{U}$ apparent ages scatter between $297 \pm 3$ and $348 \pm 3 \mathrm{Ma}$. However, four more or less distinct age groups can be defined (Fig. 10).

- group 1: $347 \pm 4$ Ma comprises only two points, 10.1 and 16.1 , both measured at Cl-dark rims of euhedral crystals;

- group 2: $323 \pm 3 \mathrm{Ma}$ consists of four points, 2.1, 8.2, 12.1 , and 14.1 , two measured in CL-bright and zoned internal parts, and two others at rims;

- group 3: $313 \pm 3$ Ma comprises five other points, 3.2, 5.1, $8.1,11.1$, and 15.1 , also representing zoned central parts or Cl-dark rims of crystals;

- group 4: $303 \pm 2 \mathrm{Ma}$ is the largest age group of 12 analytical points: 1.1, 2.2, 3.1, 4.1, 6.1, 7.1, 7.2, 8.1, 9.1, 11.2, 13.1, and 17.1

They represent various parts of crystals, including Cl-dark or zoned internal parts and mostly CL-dark rims (five analyses).

The age spectrum is difficult to interpret unequivocally (Fig. 10). Two points of Group 1 are significantly older, ca. $347 \pm$ $4 \mathrm{Ma}$. Interestingly, both of the points are located in zircon rims. Their physical and chemical features are not different from those of the younger zircons, thus they should not be treated as a real, significantly older inheritance. It is noteworthy that this age agrees well with the $\mathrm{Rb}-\mathrm{Sr}$ whole-rock isochron age of 347 \pm 12 Ma reported for the biotite granites by Oberc-Dziedzic et al. (1996).

The remaining 20 points reveal a range of $\mathrm{U}-\mathrm{Pb}$ ages between 297 and $325 \mathrm{Ma}$, overlapping within errors. In spite of that, it is possible to distinguish separate groups, with distinct Concordia ages of $323 \pm 3 \mathrm{Ma}, 313 \pm 3 \mathrm{Ma}$, and $303 \pm 2 \mathrm{Ma}$ (Fig. 10B). Although this grouping corresponds to what is actually observed, its real geological significance is problematic. The scatter of ages may result from various degrees of radiogenic lead loss in zircons and the true igneous emplacement age might be much older (e.g., as old as ca. 323 or even $347 \mathrm{Ma}$ ). Alternatively, we may have sampled variable amounts of inherited components and identified mixed age groups. Unfortunately, this question is not resolvable with the routine SHRIMP procedure; a possible way to test this in the future would be chemical abrasion (Mattinson et al., 2006; 

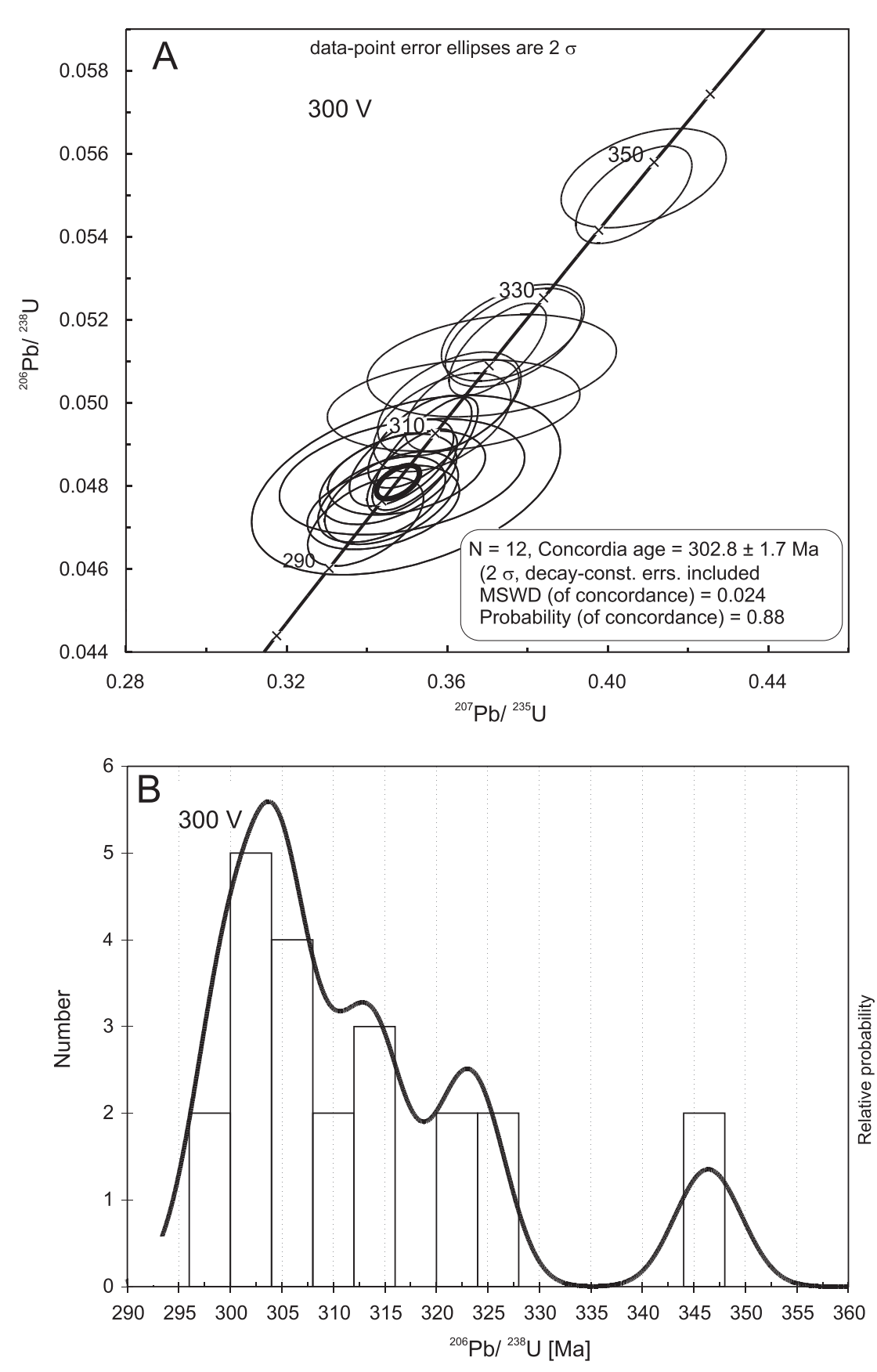

Fig. 10A - Concordia diagram for zircons from the medium-grained biotite granite, sample $300 \mathrm{~V}$; twelve analytical points of dates between ca. 290 and $350 \mathrm{Ma}$; $\mathrm{B}$ - histogram of date distribution between ca. 290 and $350 \mathrm{Ma}$

mentioned above. Chemical and physical conditions of magma evolution, slightly changing in space and time, could have resulted in the observed variation of internal features and chemical characteristics of the zircons.

A likely influence of Pb-loss effects seems to be indicated by apparently older rims and younger cores, e.g., grains 3, 7, 8 and 11 , all with high $U$ contents (around and above 1000 ppm). However, in most cases, the age difference between rim and core is barely significant at the $95 \%$ confidence level $(2 \sigma)$, e.g., grain 3 core $303 \pm 5 \mathrm{Ma}$, rim $314 \pm 6 \mathrm{Ma}$; grain 7 core $297 \pm 5 \mathrm{Ma}$, rim $304 \pm 5 \mathrm{Ma}$; grain 11 core $300 \pm 6 \mathrm{Ma}$, rim $314 \pm 6 \mathrm{Ma}$. Only grain 8 shows significant difference between core (309 $\pm 6 \mathrm{Ma})$ and $\operatorname{rim}(324 \pm 6 \mathrm{Ma})$, possibly because the core was more "dirty", and metamict and, by inference, suffered more radiogenic lead loss. Taken at face value, this rim age seems to imply a minimum age of ca. $325 \mathrm{Ma}$, because inheritance can be dismissed as a possible cause of bias in that case. This, along with the two data points 10.1 and 16.1 measured at rims of euhedral grains, with apparent ${ }^{206} \mathrm{~Pb} /{ }^{238} \mathrm{U}$ ages of $348 \pm 6(2 \sigma) \mathrm{Ma}$ and $345 \pm 6(2 \sigma) \mathrm{Ma}$, might indicate that the true emplacement age is much older than suggested by the majority of grains, which might well have suffered significant lead loss. If so, the $\mathrm{Rb}-\mathrm{Sr}$ WR isochron (Oberc-Dziedzic et al., 1996) should not be discarded too quickly. Admittedly, the Rb-Sr WR approach cannot compete in terms of precision with the U-Pb technique, and it is subject to many potential pitfalls which may lead to inaccurate results, but $\mathrm{U}-\mathrm{Pb}$ dating is not free of pitfalls either, a most critical one being the difficulty in assessing the true degree of discordance when using in situ methods (e.g., Pin and Rodriguez, 2009).

In view of the discussion above, unequivocal interpretation of the zircon age scatter in sample $300 \mathrm{~V}$ is difficult, and the true age of the main magmatic event remains uncertain. Whether the older ages of ca. $345 \mathrm{Ma}$ (in accord with the earlier Rb-Sr data) and ca. $325 \mathrm{Ma}$ correspond to early plutonic stages of the medium-grained granite, and the younger ages around 313 and $303 \mathrm{Ma}$ are related to later magmatic stages or simply reflect significant radio-

Kryza et al., 2012), aiming to remove any domain in the zircons that suffered radiogenic lead loss (discordant) in order to make ${ }^{206} \mathrm{~Pb} /{ }^{238} \mathrm{U}$ ages more reliable.

The zircons representing various ages are broadly similar and their features are typical of magmatic zircons. The absence of considerably older inheritance suggests that the magma composition and temperature were such that any older inherited component was erased. The age distribution of zircons in the medium-grained granite may reflect several pulses of magma crystallisation, spanning ca. $45 \mathrm{Ma}$ of plutonic activity, or merely reflect variable degrees of radiogenic lead loss, as genic lead loss, remains an open question that may be resolved by future detailed studies.

$$
\begin{aligned}
& \text { SAMPLE } 300 \text { IV, } \\
& \text { FINE-GRAINED GRANITE }
\end{aligned}
$$

Zircon characteristics. The zircon population comprises mostly euhedral, long- and normal-prismatic and subordinate short-prismatic crystals. Most of the crystals have two pyramids, with the shallow one predominating. The grains are clear and colourless, with rare acicular and oval inclusions. A few 


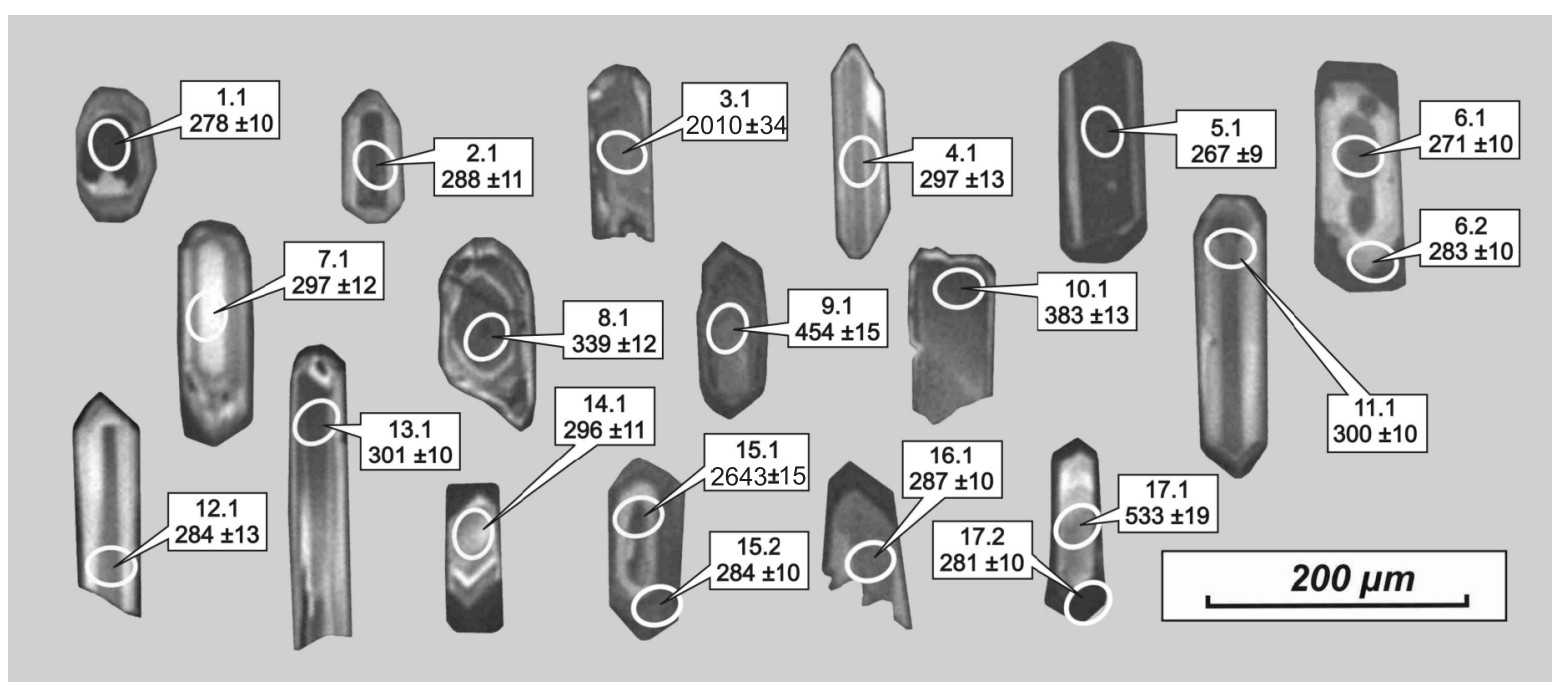

Fig. 11. CL images of selected zircons from the fine-grained biotite granite (sample $300 \mathrm{IV}$ )

grains have subhedral or irregular shapes, and many are broken (during separation?), although they do not show many cracks in reflected light.

In CL image (Fig. 11), most of the crystals are moderately bright and show fine, commonly not very distinct "magmatic" zonation. Several crystals have thin CL-dark rims, and a few other grains contain rounded, usually CL-dark cores (Fig. 11, grains 1, 6 and 8 ). The various brightness in $\mathrm{CL}$ images reflects variable $\mathrm{U}$, Th and $\mathrm{Pb}$ concentrations (Appendix 7 , and see description below).

SHRIMP ages. Twenty analytical points from 17 grains yield a wide spectrum of inherited ages dispersed between the Archean and Early Carboniferous, and the main ${ }^{206} \mathrm{~Pb} /{ }^{238} \mathrm{U}$ age population scatters around $285 \mathrm{Ma}$ (Fig. 12).

Inherited zircons. Two Archean-Paleoproterozoic ${ }^{207} \mathrm{~Pb} /{ }^{206} \mathrm{~Pb}$ discordant ages were obtained: grain 15.1 - $2643 \pm$ $15 \mathrm{Ma}$ (discordance D $+91 \%$ ), and $3.1-2010 \pm 34 \mathrm{Ma}$ (D $+10 \%$ ). Both ages are in the cores of normal-prismatic euhedral crystals, and provide minimum estimates of the true crystallisation ages. These cores show low to moderate $\mathrm{Pb}_{\mathrm{c}}$ content and low ${ }^{232} \mathrm{Th} /{ }^{238} \mathrm{U}$ ratios $(0.09-0.24)$. The calculated discordia two-point (mixing) lines, including the two inherited grains and the main age-population zircons, give intercepts at $2789 \pm$ $38 \mathrm{Ma}$ and $285 \pm 7 \mathrm{Ma}$ for the older crystal, and $2029 \pm 74 \mathrm{Ma}$ and $285 \pm 8 \mathrm{Ma}$ for the younger one (not shown in Fig. 12); the two upper intercepts might be close to the true ages of these old Precambrian zircons.

Four analytical points show ${ }^{206} \mathrm{~Pb} /{ }^{238} \mathrm{U}$ ages scattered within a range of 339-533 Ma, clearly older than the main age population: $17.1-533 \pm 19 \mathrm{Ma}, 9.1-454 \pm 15 \mathrm{Ma}, 10.1-383$ $\pm 13 \mathrm{Ma}$ and $8.1-339 \pm 12 \mathrm{Ma}$ (Fig. 12A). Apart from point 10.1 , which is near the edge of a subhedral crystal, the remaining three represent the internal portions of crystals. Point 8.1 is located within a distinct core. All the crystals display generally low $\mathrm{Pb}_{\mathrm{c}}$ contents $(0.16-0.50 \%)$ and moderate to high ${ }^{232} \mathrm{Th} /{ }^{238} \mathrm{U}$ ratios $(0.34-1.24)$. Discordance ranges between -9 and $+27 \%$.

Zircons with ${ }^{206} \mathrm{~Pb} /{ }^{238} \mathrm{U}$ ages around $285 \mathrm{Ma}$. This age group comprises 14 analytical points with ${ }^{206} \mathrm{~Pb} /{ }^{238} \mathrm{U}$ ages in the range from 270 and $301 \mathrm{Ma}$ (Appendix 7 and Fig. 12). They represent both the cores (points 1.1, 2.1, 4.1, 5.1, 6.1, 7.1, 14.1,
16.1) and rims $(6.2,11.1,12.1,13.1,15.2,17.2)$ of euhedral crystals. A few of these points have relatively high $\mathrm{Pb}_{\mathrm{c}}$ contents (up to $3.7 \%$ in point 12.1 ), and the ${ }^{232} \mathrm{Th} /{ }^{238} \mathrm{U}$ ratios vary between 0.08 and 1.47 (mostly between 0.30 and 1.00). The age discordance $\mathrm{D}$ varies between $-350 \%$ (grain 12.1) and +158 (grain 7.1; in spite of the high $D$ values, which is not unusual in younger Phanerozoic zircons, the $2 \sigma$ error ellipses overlap the Concordia line). The entire group (including points with high discordance D) would give a Concordia age of $285 \pm 5 \mathrm{Ma}(2 \sigma)$. A selection of six points with relatively smaller discordance (between -1 and $+52 \%): 1.1,5.1,6.2,13.1,15.2$, and 16.1 , yields a slightly lower Concordia age of $283 \pm 8 \mathrm{Ma}(2 \sigma)$. Point 7.1 , with discordance of $+158 \%$, most likely reflects the presence of an old inherited component, as indicated by its ${ }^{207} \mathrm{~Pb} /{ }^{206} \mathrm{~Pb}$ age of ca. $700 \mathrm{Ma}$.

Summing up, the fine-grained granite 300 IV contains considerable amounts of inherited zircons of various ages: Archean-Paleoproterozoic and Paleozoic, up to ca. $340 \pm$ $12 \mathrm{Ma}$. This strongly suggests that the magma was generated from "inhomogeneous" source (e.g., metasedimentary material) or was contaminated by such materials.

The zircons of the main age-population are fairly homogeneous as to the crystal habit and their other physical features, although they are diverse in chemical characteristics, the latter suggesting possible chemical variations during a prolonged magma-crystallisation process. The individual grains show ${ }^{206} \mathrm{~Pb} /{ }^{238} \mathrm{U}$ ages scattered between ca. 270 and $301 \mathrm{Ma}$, but the mean concordant age of $283 \pm 8 \mathrm{Ma}$ calculated for a selection of points with lower discordance $D$ values could be interpreted as the age of the main magmatic crystallisation event in this fine-grained granite. Based on the discussion above, this interpretation should be treated with caution, though it is clear that this sample does not show evidence for an age clearly in excess of ca. $300 \mathrm{Ma}$, in contrast with the previous sample of medium-grained granite.

SAMPLE $300 \mathrm{VI}$, FINE-GRAINED GRANITE

Zircon characteristics. The zircon population in this sample is fairly homogeneous as to the habit and internal structure 

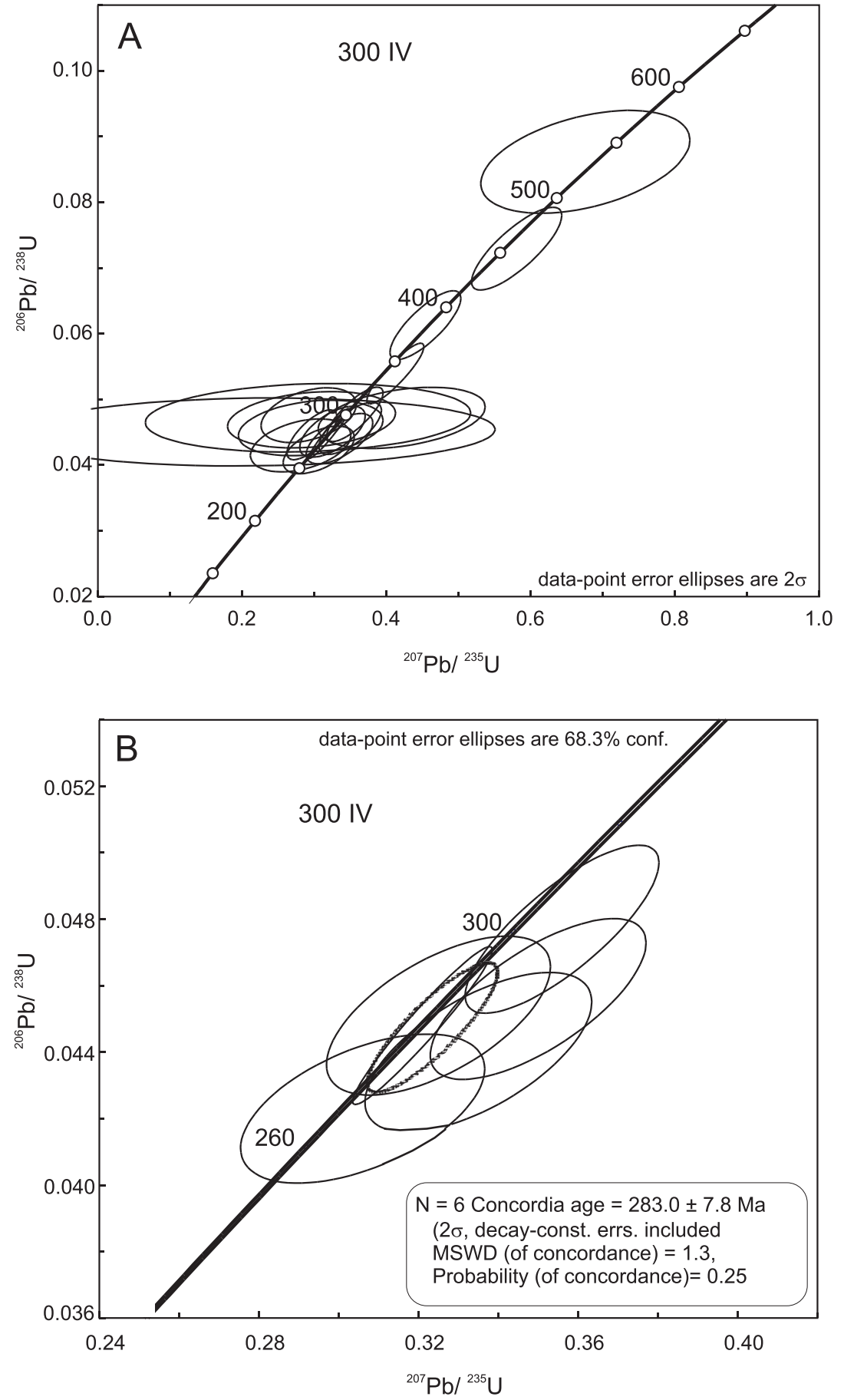

Fig. 12 Concordia diagrams for zircons from the fine-grained Bt granite (sample $300 \mathrm{IV}$ )

A - analytical points with dates between ca. 270 and 550 Ma; B - mean Concordia age of around $283 \mathrm{Ma}$ for six selected zircons of the main age group

of the crystals, and similar to that in sample $300 \mathrm{IV}$. The zircons are colourless and transparent, mostly euhedral and normal prismatic, with shallow prisms dominating. A few crystals have two well-developed pyramids which results in a barrel-shape of the grains. Rather exceptional are irregular or subhedral grains. Many crystals are broken. Small inclusions of various shapes, oval and acicular, are generally rare.
In CL images (Fig. 13), most of the zircons display distinct magmatic zonation, parallel to the external faces of grains or, in elongated crystals, parallel to the long axis. A few crystals display more or less distinct internal parts, some oval in shape (e.g., grain 42), indicating likely dissolution processes. The internal parts are commonly CL darker; one such grain (points $37.1,37.2)$ shows "reverse core-rim ages" (see below; Fig. 13).

The zircons are mostly moderately rich in $U$ (157-627 ppm, with three points between $3422-3935 \mathrm{ppm})$; Th is relatively high (68-513 ppm, up to $1518 \mathrm{ppm}$ in the high-U grains; Appendix 8). The ${ }^{232} \mathrm{Th} /{ }^{238} \mathrm{U}$ ratios are rather uniform and moderate, between 0.21 and 0.97 (one grain is exceptionally low, at 0.08 ). Common lead ${ }^{206} \mathrm{~Pb}_{\mathrm{c}}$ is relatively high, above $1.0 \%$ in 14 points, out of 21 (and up to $3.3 \%$ ).

SHRIMP ages. This sample has been measured twice: the first SHRIMP session, with some instrumental instability, was repeated; 21 analytical points in 19 grains were analysed in the second session (Appendix 8). In spite of that, the data from this sample still seem to be of poor quality. In particular, there are several data points with huge reverse discordance, e.g., 31.1, 32.1, 38.1, 41.1, 46.1 and 49.1. These data cannot be used for age calculation, because they reflect either a poor calibration of the machine for $\mathrm{U} / \mathrm{Pb}$ ratio, or an inappropriate correction for common lead, or both. In spite of the apparent poor precision of these data, we have decided to include them in this paper, because we get a general confirmation of the presence of inheritance in the fine-grained granites, as well as broadly similar ages of the main zircon populations in both samples of this granite type.

Four analytical points represent clear inheritance: point 39.2 (core) $-600 \pm$ $11 \mathrm{Ma}, 39.1$ (rim) - $525 \pm 10 \mathrm{Ma}, 45.1-$ $451 \pm 9 \mathrm{Ma}$, and $42.1-373 \pm 7 \mathrm{Ma}$. All these are euhedral, with fine magmatic zonation. In session 1 (results not listed in Appendix 8), one grain of ca. $1.9 \mathrm{Ga}$ ${ }^{207} \mathrm{~Pb} /{ }^{206} \mathrm{~Pb}$ age, and three others with ${ }^{206} \mathrm{~Pb} /{ }^{238} \mathrm{U}$ apparent ages between 422 and $437 \mathrm{Ma}$ were measured).

Fourteen analyses plot within a broadly coherent cluster of ages, within the range of 286-312 Ma (Fig. 14A). One point, 43.1, rich in $\mathrm{U}$ and $\mathrm{Th}$ and with high ${ }^{206} \mathrm{~Pb}_{\mathrm{c}}$, gives an unrealistically young, $166 \pm 3 \mathrm{Ma}^{206} \mathrm{~Pb} /{ }^{238} \mathrm{U}$ age.

Excluding the evidently inherited zircons, as well as the points with very high discordance $D$ (i.e., 31.1, 32.1, 38.1, 41.1, $46.1,49.1)$, the remaining 11 points give a Concordia age of $298 \pm 4 \mathrm{Ma}$ (Fig. 14B). However, two points in that group are significantly younger, thus allowing one to define two possible subsets of ages: at ca. $302 \mathrm{Ma} \mathrm{(12} \mathrm{points)} \mathrm{and} \mathrm{ca.} 286 \mathrm{Ma} \mathrm{(2}$ points). 


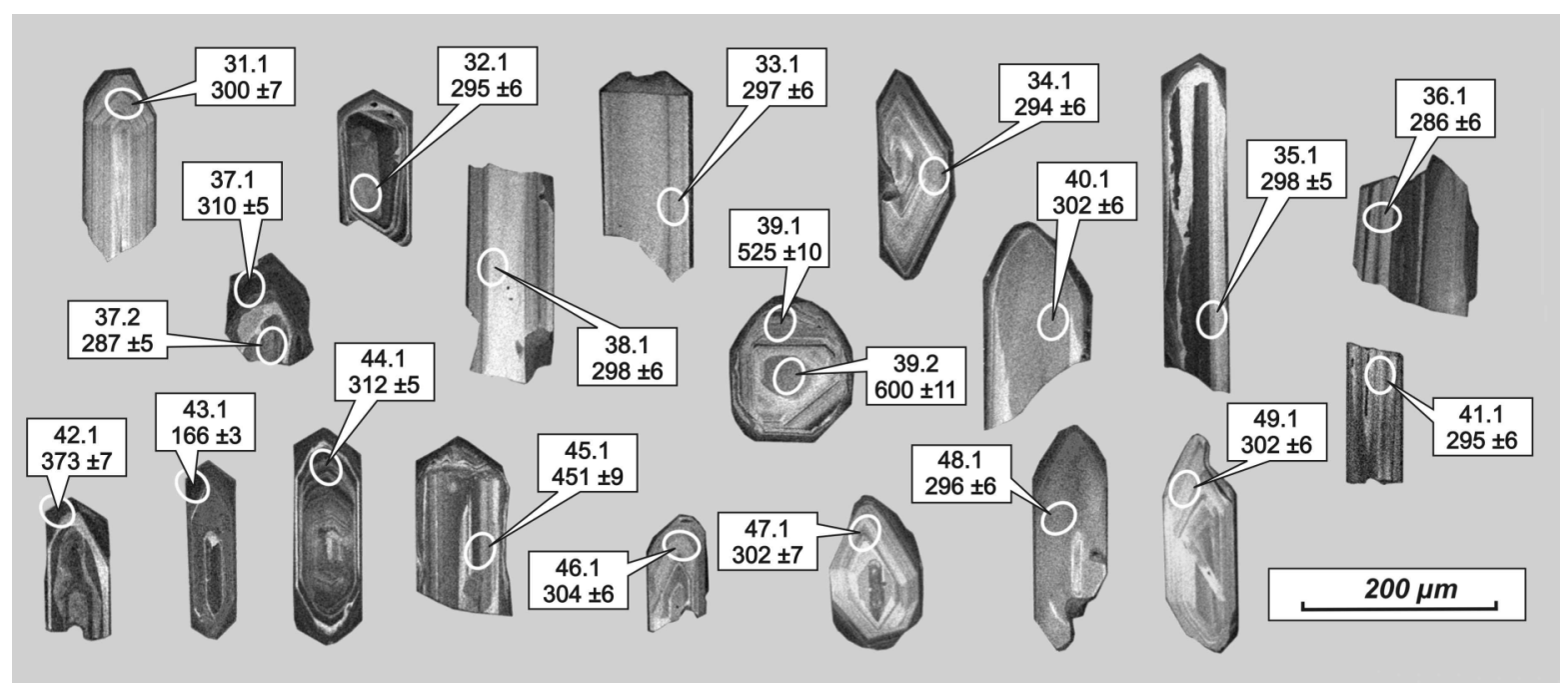

Fig. 13. CL images of selected zircons from the fine-grained biotite granite (sample $300 \mathrm{VI}$ )

Keeping in mind the seemingly not very high quality of the data from the second sample of the fine-grained granite, we should notice that the calculated ages in this sample fall within the same range, i.e. between ca. 285 and 300 Ma. Excluding the clearly older inherited fractions, there is no evidence of earlier magmatic events that have been shown as likely in the medium-grained granite.

\section{SUMMARY AND DISCUSSION}

\section{SUMMARY OF THE SHRIMP AGES}

The age spectrum of zircons in the medium-grained granite is difficult to interpret unequivocally. Two points yielded significantly older dates (ca. $347 \mathrm{Ma}$ ), though the scarcity of considerably older inheritance suggests that the magma-generating processes were intense enough to erase the older mineral components.

Most of the zircons (20 points) in the medium-grained granite give ${ }^{206} \mathrm{~Pb} / /^{238} \mathrm{U}$ ages that are relatively widely distributed between 297 and $325 \mathrm{Ma}$, overlapping within errors. In spite of that, it is possible to distinguish separate subsets, with distinct Concordia ages of $323 \pm 3 \mathrm{Ma}, 313 \pm 3 \mathrm{Ma}$, and $303 \pm 2 \mathrm{Ma}$. This age distribution may reflect several stages of magma crystallisation, spanning long-lasting plutonic activity. If this assumption is correct, the date of $303 \pm 2$ Ma would correspond with the final stage of crystallisation of the medium-grained granite, likely during its emplacement. Alternatively, the age distribution of zircons in the medium-grained granite may reflect variable degrees of radiogenic lead loss from zircons having a minimum age of ca. $323 \mathrm{Ma}$, and possibly as old as ca. $347 \mathrm{Ma}$. The zircons representing various ages in this medium-grained granite are broadly similar and their textural features are typical of magmatic zircons. The chemical and physical conditions of magma evolution, slightly changing in space and time, could have resulted in the observed variation of internal features and chemical characteristics of the zircons.

The fine-grained granites also show considerable variation in zircon ages. Sample 300 IV shows a dispersion of ${ }^{206} \mathrm{~Pb} /{ }^{238} \mathrm{U}$ ages between ca. 270 and $301 \mathrm{Ma}$, with an average Concordia age of $283 \pm 5 \mathrm{Ma}$, that could be interpreted to date the main magmatic event in the fine-grained granite. However, the real age of the main magmatic event could be significantly older, e.g., around $300 \mathrm{Ma}$, if the zircons suffered some radiogenic lead loss. The other sample of the fine-grained granite, $300 \mathrm{VI}$, also has ${ }^{206} \mathrm{~Pb} /{ }^{238} \mathrm{U}$ ages varying from 286 to $312 \mathrm{Ma}$, with most clustering between ca. 286 and $302 \mathrm{Ma}$. Thus, both samples of the fine-grained granites contain zircons with ages corresponding in time to the likely final magmatic event recorded in the medium-grained granite, at ca. $300 \mathrm{Ma}$.

Based on the SHRIMP results presented in this paper, the zircon ages in the medium-grained granite in the Strzelin intrusion may indicate long-lasting plutonic activities, between ca. 325 (or even ca. $347 \mathrm{Ma}$ ) and ca. $303 \mathrm{Ma}$; however, this tentative conclusion is difficult to prove unequivocally based on the data so far available; the scatter of ${ }^{206} \mathrm{~Pb} /{ }^{238} \mathrm{U}$ apparent ages might, alternatively, reflect variable degrees of radiogenic lead loss. Subsequent igneous activity produced younger finegrained granites, with the final important magmatic event possibly as young as ca. $286 \mathrm{Ma}$. Thus, the protracted granite plutonism might have been a complex process, lasting at least ca. 40 (and perhaps 60) Ma.

\section{COMMENTS ON THE Rb-Sr SYSTEMATICS}

The Strzelin intrusion granites were previously dated using the $\mathrm{Rb}-\mathrm{Sr}$ whole-rock isochron method (Oberc-Dziedzic et al., 1996). $\mathrm{Rb}$ and Sr concentrations were determined in 7 samples of medium and fine-grained biotite granites, and 2 samples of biotite-muscovite granite. The biotite granites were believed to be synchronous and cogenetic, so an isochron was computed for all 7 samples. The isochron age was interpreted as the age of the igneous emplacement of the granites: $347 \pm 12 \mathrm{Ma}$, with an initial ${ }^{87} \mathrm{Sr} /{ }^{86} \mathrm{Sr}=0.7053 \pm 2$ following model 2 of Ludwig's (1994) software. The relatively high MSWD value (2.9), reflecting a scatter of the data points higher than predicted by analytical uncertainties alone, was interpreted as a sign of "limited degrees of $\mathrm{Sr}$ isotopic heterogeneity of the granitic magma when it 

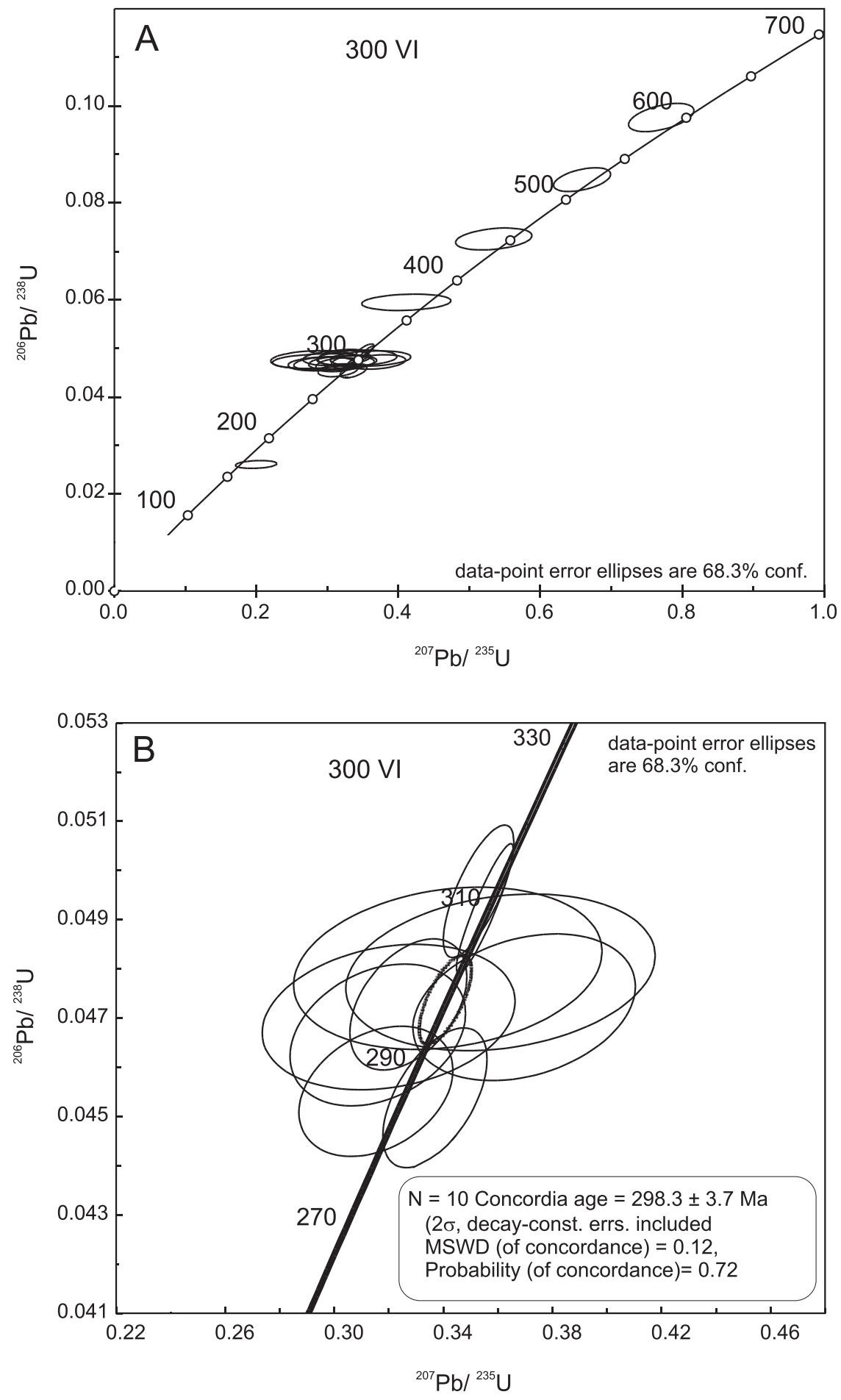

Fig. 14. Concordia diagrams for zircons from the fine-grained granite (sample $\mathbf{3 0 0} \mathrm{VI}$ )

A - all analytical points; B - mean Concordia age of around $298 \mathrm{Ma}$ for ten selected zircons of the main age group biotite-muscovite granite, similar to that of the biotite granites, was interpreted to suggest similar sources with low time-integrated $\mathrm{Rb} / \mathrm{Sr}$ ratios. However, new $\mathrm{Sm}-\mathrm{Nd}$ data document a less radiogenic source for the two-mica granites. This might be interpreted to reflect either separate sources, or the occurrence of more contamination by crustal materials of a common parental magma, during differentiation from biotite granite to two-mica granite.

The good Rb-Sr isotope homogeneity of the biotite granites illustrated by the whole-rock isochron (Oberc-Dziedzic et al., 1996), and the lack of evidence for mixing (no hyperbolic trend in $a^{87} \mathrm{Sr} /{ }^{86} \mathrm{Sr}$ vs Sr plot; Oberc-Dziedzic et al., 1996) is difficult to explain because, in the light of our new investigations, the mediumgrained and fine-grained biotite granites are not cogenetic and likely came from different sources or, at least, were contaminated to different degrees. However, it is noteworthy that, in this contamination scenario, the typical contrast of concentrations of $\mathrm{Sr}$ and $\mathrm{Nd}$ between the initial magma (with high $\mathrm{Sr} / \mathrm{Nd}$ ) and crustal contaminant (with low $\mathrm{Sr} / \mathrm{Nd}$ ) is such that the $\mathrm{Sr}$ isotope system is a much less sensitive monitor of contamination than the Nd isotope system, at least for relatively small degrees of assimilation of a crustal endmember. This might account for the relatively good homogeneity of $\mathrm{Sr}$ isotopes suggested by the Rb-Sr WR isochron.

The good $\mathrm{Rb}-\mathrm{Sr}$ isotope homogeneity of the biotite granites also indicates that the $\mathrm{Rb}-\mathrm{Sr}$ system remained unaffected during postmagmatic hydrothermal processes (Ciesielczuk and Janeczek, 2004; Ciesielczuk, 2007).

The above comments show that the large age discrepancies between the ages of medium-grained and fine-grained biotite granites of the Strzelin intrusion obtained by $\mathrm{Rb}-\mathrm{Sr}$ and SHRIMP methods are difficult to explain without further detailed investigations.

\section{ORIGIN OF THE GRANITE MAGMAS}

The three types of granites forming the Strzelin intrusion show some differences in major element contents that are reflected in the proportions of rock-forming minerals and their chemical compositions (Figs. 5 and 6). Such differences was emplaced" (Oberc-Dziedzic et al., 1996). A younger age of $330 \pm 6 \mathrm{Ma}$, with ${ }^{87} \mathrm{Sr}^{86} \mathrm{Sr}_{\mathrm{i}}=0.7053 \pm 8$ was calculated from the two samples of the biotite-muscovite granite from the Strzelin intrusion and 2 other samples of the biotite-muscovite granite from Gębczyce (Fig. 1C). The relatively low ${ }^{87} \mathrm{Sr}^{86} \mathrm{Sr}_{i}$ ratio of the would suggest that the three granites are products of differentiation of a common magma batch. In this case, portions of differentiated magma should have been evolved in a sequence reflecting increasing $\mathrm{SiO}_{2}$ : from the fine-grained granite, through the medium-grained granite, to the biotite-muscovite 
granite. However, this scenario cannot be accepted because the field observations show that granites were instead emplaced in the following sequence:

1) medium-grained granite;

2) fine-grained granite;

3) biotite-muscovite granite.

The field relationships were confirmed by the SHRIMP age data which show that the medium-grained granite contains zircon populations that are significantly older than the main zircon populations in the fine-grained granite. Such age relationships indicate that the magmas of the three granite types represent, most likely, separate magma batches. However, some textural and compositional features, e.g., the differences in grain size, proportions of main minerals and compositional patterns in plagioclase observed in the fine-grained granite reflect significant differentiation processes within this granite magma.

Although the medium- and fine-grained biotite granites have different zircon age spectra and show differences in major element contents, their trace element characteristics are similar, but different from those of the biotite-muscovite granite. This difference suggests that their magmas originated from different sources. The trace-element patterns of both the biotite granites are similar to upper continental crust, namely they show only slight (less that 10\%) but systematic elevation of the trace element contents, and no negative $\mathrm{Nb}, \mathrm{Ti}, \mathrm{P}$ and $\mathrm{Sr}$ anomalies (when normalized to upper crust composition). Thus, it is very likely that the magmas of both the biotite granites derived from melting of continental crust materials. The source rocks of the fine-grained biotite granite magma must have been more basic in composition, as indicated by the lower $\mathrm{SiO}_{2}$ contents and higher $\mathrm{Mg}$ in biotite, compared to those in the medium-grained biotite magma. The clearly different trace-element patterns for the biotite-muscovite granites, normalized to the upper continental crust, strongly suggest their derivation from a different crustal source and, possibly, also a lower degree of partial melting.

Similar suggestions about the origin of the Strzelin granites magmas come from the isotope data. If an igneous emplacement age of ca. $300 \mathrm{Ma}$ is favoured, then the age-corrected $\mathrm{Sr}$ isotope signature for the biotite and biotite-muscovite granites differ, with ${ }^{87} \mathrm{Sr}^{86} \mathrm{Sr}_{\mathrm{i}=300} \mathrm{Ma}$ of 0.7070 for sample STIN 3 (fine-grained biotite granite, Appendix 4) and 0.716-0.722 for samples STIN 1 and STIN 2 (biotite-muscovite granite, Appendix 4), respectively (recalculated from Oberc-Dziedzic et al., 1996), suggesting their derivation from different sources. The $\varepsilon \mathrm{Nd}_{300}$ value (Appendix 5) in the fine-grained biotite granite $(-3.8)$ is significantly higher than in the biotite-muscovite granite $(-5.4,-5.8)$ reflecting a greater proportion of a component with somewhat higher time-integrated $\mathrm{Sm} / \mathrm{Nd}$ ratio. Overall, the negative $\varepsilon \mathrm{Nd}_{\mathrm{i}}$ values in the granites are interpreted to indicate a predominantly crustal source of the magmas. The slightly more radiogenic signature of the biotite granite compared with that of the biotite-muscovite granite might reflect the subordinate involvement of a mafic mantle-derived material during magma generation or, alternatively, derivation from more immature (that is, younger and/or with higher $\mathrm{Sm} / \mathrm{Nd}$ ratios) crustal protoliths.

Some evidence concerning the source material is recorded in the zircons. In the medium-grained biotite granite, considerably older inheritance is absent, which suggests that older zircon populations were erased during the magma-generating processes. In contrast, the fine-grained biotite granite contains inherited zircons of various ages, among them Neoproterozoic grains with ca. $600-560 \mathrm{Ma}$ ages. Such an age range is typically observed in zircons from gneisses of the Strzelin Complex (as part of Brunovistulicum; Oberc-Dziedzic et al., 2003; Klimas, 2008) or in inherited zircon cores from gneisses of the Stachów Complex (part of Moldanubicum) dated at ca. 500 Ma. This strongly suggests that the magma of the fine-grained biotite granite was generated from a source similar to the Neoproterozoic rocks and/or suffered contamination by Lower Paleozoic gneisses, all forming the envelope of the Strzelin intrusion.

\section{CONCLUSIONS}

1. The Strzelin intrusion, composed of three various granite types (medium-grained biotite granite, fine-grained biotite granite, and fine-grained biotite-muscovite granite), had a prolonged and complex evolution as shown by petrological and geochronological data.

2. The petrographic and geochemical features, as well as the $\mathrm{Nd}$ isotope data and zircon inheritance, suggest that the magmas of the three granites were derived from various crustal sources.

3. The available zircon age data do not allow defining of the true igneous emplacement ages of the granites unequivocally, because the scattered spectra may reflect:

- prolonged or multi-phase magmatic crystallisation events,

- various admixture of inheritance, and

- various degrees of radiogenic lead loss during late- or post-magmatic stages.

Unfortunately, these problems are not easy to resolve based on the conventional SHRIMP zircon data available.

4. Based on the scattered zircon age spectra, it is possible that the true magmatic age of the oldest medium-grained biotite granite is $325 \mathrm{Ma}$ (or even $\sim 345 \mathrm{Ma}$ ?) as reflected by the ages of a few zircons in this granite. The main clusters of younger ages around 313 and $303 \mathrm{Ma}$ can be interpreted either as related to younger magmatic stages, or to radiogenic lead loss.

5. Based on geological and geochronological evidence, the fine-grained biotite granite is younger. The two samples measured by SHRIMP do not favour an age in excess of ca. $300 \mathrm{Ma}$. The main zircon age population groups around 300 and $285 \mathrm{Ma}$ may reflect magmatic crystallisation events. However, the younger set of dates particularly could also have been produced by lead loss in zircons that crystallised during the ca. $300 \mathrm{Ma}$ magmatic stage. This needs to be tested by future investigations.

6 . The fine-grained biotite-muscovite granite postdates both the biotite granites, as clearly shown by field relationships.

7. New age data suggest that the granites of the Strzelin intrusion belong to the second and third stages of magmatism in the Strzelin Massif.

Acknowledgements. The research was carried out under the Project N307 008 32/0314 of the Polish Ministry of Science and Education. Additional support came from internal grants $1017 /$ S/ING and 2022/W/ING of the University of Wrockaw. P. Dzierżanowski and L. Jeżak are acknowledged for their help 
and assistance with EMP analyses. The SHRIMP zircon analyses were performed in the Centre of Isotopic Research (CIR) at the All-Russian Geological Research Institute (VSEGEI) in St. Petersburg, and in the Beijing SHRIMP Center, Chinese Academy of Geological Sciences. K. Ochnik is acknowledged for as- sistance during exploration of the Strzelin I quarry abyss. Dr. J. Ciesielczuk, Prof. W. Siebel and an anonymous reviewer are thanked for their detailed and constructive reviews.

\section{REFERENCES}

Aleksandrowski P., Mazur S. (2002) Collage tectonics in the northeasternmost part of the Variscan Belt: the Sudetes, Bohemian Massif. Geological Society Special Publications, 201: 237-277.

Barrière M. (1981) On curved laminae, graded layers, convection currents and dynamic crystal sorting in the Ploumanach (Brittany) subalkaline granite. Contributions to Mineralogy and Petrology, 77: 214-224.

Bereś B. (1969) Petrography of granite of the environments of Strzelin (in Polish with English summary). Archiwum Mineralogiczne, 28 (2): 5-105.

Black L.P., Kamo S.L., Allen C.M., Aleinikoff J.N., Davis D.W., Korsch R.J., Foudoulis C. (2003) TEMORA 1: a new zircon standard for Phanerozoic U-Pb geochronology. Chemical Geology, 200: 155-170.

Ciesielczuk J. (2007) Hydrothermal activity in the Strzelin granite, SW Poland. AM Monograph 1: 231-242.

Ciesielczuk J., Janeczek J. (2004) Hydrothermal alteration of the Strzelin granite, SW Poland. Neues Jahrbuch für Mineralogie Abhandlungen, 179: 239-264.

Cháb J., Žaček V. (1994) Geology of the Žulová pluton mantle (Bohemian Massif, Central Europe). Vestník Ceského geologického ústavu, 69 (4): 1-12.

Cháb J., Mixa P., Vaneček M., Žaček V. (1994) Geology of the NW part of the Hrubý Jeseník Mts. (the Bohemian massif, Central Europe). Vestník Ceského geologického ústavu, 69 (3): 17-26.

Cloos H. (1921) Der Mechanismus Tiefvulkanischer Vorgange. Sammlung Vieweg \& Sohn, Braunschweig.

Cloos H. (1922) Die Gebirgsbau Schlesien und die Stellung seiner Bodenschätze. Verlag von Gebrüder Borntraeger, Berlin.

Cymerman Z., Piasecki M.A.J. (1994) The terrane concept in the Sudetes, Bohemian Massif. Geological Quarterly, 38 (2): 191-210.

Cymerman Z., Piasecki M.A.J., Seston R. (1997) Terranes and terrane boundaries in the Sudetes, north east Bohemian Massif. Geological Magazine, 134: 717-725.

De Paolo J. (1981a) Neodymium isotopes in the Colorado Front Range and crust - mantle evolution in the Proterozoic. Nature, 291: 193-196.

De Paolo J. (1981b) A Nd and Sr isotopic study of Mesozoic calc-alkaline batholiths of the Sierra Nevada and Peninsular Ranges, California. Journal of Geophysical Research, 86: 10370-10488.

Didier J. (1973) Granites and their enclaves. The bearing of enclaves on the origin of granites. Elsevier, Amsterdam.

Dudek A. (1980) The crystalline basement block of the outer Carpathians in Moravia-Bruno-Vistulicum. Rozpravy Československé Akademie Véd, Řada matematických a prirodnich Véd, 90: 1-85.

Finger F., Frasl G., Höck V., Steyrer H.P. (1989) The granitoids of the Moravian Zone of northeast Austria: products of a Cadomian active continental margin? Precambrian Research, 45: 235-245.

Finger F., Roberts M.P., Haunschmid B., Schermaier A., Steyrer H.P. (1997) Variscan granitoid of central Europe: their topology, potential sources and tectonothermal relations. Mineralogy and Petrology, 61: 67-96

Finger F., Hanžl P., Pin C., von Quadt A., Steyrer H.P. (2000) The Brunovistulian: Avalonian Precambrian sequence at the eastern end of the Central European Variscides? Geological Society, Special Publications, 179: 103-112.

Franke W. (1989) Tectonostratigraphic units in the Variscan belt of Central Europe. GSA Special Paper, 230: 67-89.

Franke W. (2000) The mid-European segment of the Variscides: tectonostratigraphic units, terrane boundaries and plate tectonic evolution. Geological Society of London, Special Publications, 179: $35-61$.

Franke W. (2012) Comment on Dörr and Zulauf: elevator tectonics and orogenic collapse of a Tibetan-style plateau in the European Variscides: the role of the Bohemian shear zone. International Journal of Earth Sciences, 101: 2027-2034.

Franke W., Żelaźniewicz A. (2000) The eastern termination of the Variscides: terrane correlation and kinematic evolution. Geological Society Special Publications, 179: 63-86.

Franke W., Żelaźniewicz A. (2002) Structure and evolution of the Bohemian Arc. Geological Society Special Publications, 201: 279-293.

Franke W., Żelaźniewicz A., Porębski S.J., Wajsprych B. (1993) Saxothuringian zone in Germany and Poland: differences and common features. Geologische Rundschau, 82: 583-599.

Friedl G., Finger F., McNaughton N.J., Fletcher J.R. (2000) Deducing the ancestry of terranes: SHRIMP evidence for South America - derived Gondwana fragments in central Europe. Geology, 28: 1035-1038.

Frost B.R., Barnes C.G., Collins W.J., Arculus R.J., Ellis D.J., Frost C.D. (2001) A geochemical classification for granitic rocks. Journal of Petrology, 11: 2033-2048.

Haskin L.A., Haskin M.A., Frey F.A., Wildman T.R. (1968) Relative and absolute terrestrial abundances of the rare earths. In: Origin and Distribution of the Elements (ed. L.H. Ahrens): 889-912. Pergamon Press, New York.

Klimas K. (2008) Geochronology and petrogenetical study of zircons from selected crystalline rocks in the eastern part of the Fore-Sudetic Block (in Polish with English summary). Uniwersytet Wrocławski, Instytut Nauk Geologicznych, Wrocław.

Klimas K., Kryza R., Fanning C.M. (2009) Palaeo- to Mesoproterozoic and Ediacaran anatexis recorded in gneisses at the NE margin of the Bohemian Massif: SHRIMP zircon data from the Nowolesie gneiss, Fore-Sudetic Block (SW Poland). Geologia Sudetica, 41: 25-42.

Kossmat F. (1927) Gliederung des varistischen Gebirgsbaues. Abhandlungen Sächsischen Geologischen Landesamts, 1: 1-39.

Kryza R., Crowley Q.G., Larionov A., Pin C., Oberc-Dziedzic T., Mochnacka K. (2012) Chemical abrasion applied to SHRIMP zircon geochronology: an example from the Variscan Karkonosze Granite (Sudetes, SW Poland). Gondwana Research, 21: 757-767. 
Larionov A.N., Andreichev V.A., Gee D.G. (2004) The Vendian alkaline igneous suite of northern Timan: ion microprobe U-Pb zircon ages of gabbros and syenite. Geological Society Memoirs, 30: 69-74.

Lorenc M.W. (1984) Endogenous enclosures (autoliths) as evidence of magmatic origin of the Strzelin granitoids (in Polish with English summary). Geologia Sudetica, 19: 75-97.

Ludwig K.R. (1994) Isoplot: a plotting and regression program for radiogenic isotope data, version 2.71. U.S. Geological Survey Open File Report, 91-445: 44.

Ludwig K.R. (2005a) SQUID 1.12 A User's Manual. A Geochronological Toolkit for Microsoft Excel. Berkeley Geochronology Center Special Publication: 1-22, http://www.bgc.org/klprogrammenu.html.

Ludwig K.R. (2005b) User's Manual for ISOPLOT/Ex 3.22. A Geochronological Toolkit for Microsoft Excel. Berkeley Geochronology Center Special Publication, 1-71, http://www.bgc.org/klprogrammenu.html.

Matte P., Maluski H., Rajlich P., Franke W. (1990) Terrane boundaries in the Bohemian Massif: results of large scale Variscan shearing. Tectonophysics, 177: 151-170.

Mattinson J.M., Hourigan J., Wooden J. (2006) Better U-Pb zircon standards for SIMS and LA-ICPMS? Preliminary results of detailed characterization and pre-treatment using CA-TIMS. American Geophysical Union, Fall Meeting 2006, abstract.

Mazur S., Aleksandrowski P., Kryza R., Oberc-Dziedzic T. (2006) The Variscan Orogen in Poland. Geological Quarterly, 50 (1): 89-118.

Mazur S., Aleksandrowski P., Turniak K., Awdankiewicz M. (2007) Geology, tectonic evolution and Late Palaeozoic magmatism of Sudetes - an overview. AM Monograph, 1: 59-87.

Mazur S., Kröner A., Szczepański J., Turniak K., Hanžl P., Melichar R., Rodionov N.V., Paderin I., Sergeev S.A. (2010) Single zircon $\mathrm{U}-\mathrm{Pb}$ ages and geochemistry of granitoid gneisses from SW Poland: evidence for an Avalonian affinity of the Brunian microcontinent. Geological Magazine, 147 (4): 508-526.

Morawski T., Kościówko H. (1975) Granity rejonu Strzelina i ich kontakty. Przewodnik 47 Zjazdu Polskiego Towarzystwa Geologicznego, Warszawa: 181-183.

Nakamura N. (1974) Determination of REE, Ba, Fe, Mg, Na and K in carbonaceous and ordinary chondrites. Geochimica et Cosmochimica Acta, 38: 757-775.

Oberc J. (1966) Geology of crystalline rocks of the Wzgórza Strzelińskie Hills, Lower Silesia (in Polish with English summary). Studia Geologica Polonica, 20: 1-187.

Oberc J., Oberc-Dziedzic T., Klimas-August K. (1988) Geological map of the Strzelin Hills $(1: 25,000)$ (in Polish) (ed. J. Oberc). Instytut Nauk Geologicznych Uniwersytetu Wrocławskiego, Przedsiębiorstwo Geologiczne Wrocław.

Oberc-Dziedzic T. (1991) Geological setting of the Strzelin granitoids (in Polish with English summary). Acta Universitatis Wratislaviensis, 1375, Prace Geologiczno-Mineralogiczne, 29: 295-324.

Oberc-Dziedzic T. (1999) The metamorphic and structural development of gneisses and older schist series in the Strzelin Crystalline Massif (Fore-Sudetic Block, SW Poland). Mineralogical Society of Poland, Special Papers, 14: 10-21.

Oberc-Dziedzic T. (2007) Internal structure of the granite and tonalite intrusions in the Strzelin massif, Fore-Sudetic block, SW Poland. AM Monograph, 1: 217-229.

Oberc-Dziedzic T., Kryza R. (2012) Late stage Variscan magmatism in the Strzelin Massif (SW Poland): SHRIMP zircon ages of tonalite and Bt-Ms granite of the Gęsiniec intrusion. Geological Quarterly, 56 (2): 225-236

Oberc-Dziedzic T., Madej S. (2002) The Variscan overthrust of the Lower Palaeozoic gneiss unit on the Cadomian basement in the Strzelin and Lipowe Hills massifs, Fore-Sudetic Block, SW Poland; is this part of the East-West Sudetes boundary? Geologia Sudetica, 34: 39-58.
Oberc-Dziedzic T., Pin C., Duthou J.L., Couturie J.P. (1996) Age and origin of the Strzelin granitoids (Fore-Sudetic Block, Poland): ${ }^{87} \mathrm{Rb} /{ }^{86} \mathrm{Sr}$ data. Neues Jahrbuch für Mineralogie Abhandlungen, 171: 187-198.

Oberc-Dziedzic T., Kryza R., Klimas K., Fanning M.C. (2003) SHRIMP U/Pb zircon geochronology of the Strzelin gneiss, SW Poland: evidence for a Neoproterozoic thermal event in the Fore-Sudetic Block, Central European Variscides. International Journal of Earth Sciences, 92: 701-711.

Oberc-Dziedzic T., Kryza R., Klimas K., Fanning M.C., Madej S. (2005) Gneiss protolith ages and tectonic boundaries in the NE part of the Bohemian Massif (Fore-Sudetic Block, SW Poland). Geological Quarterly, 49 (4): 363-378.

Oberc-Dziedzic T., Kryza R., Białek J. (2010) Variscan multistage granitoid magmatism in Brunovistulicum: petrological and SHRIMP U-Pb zircon geochronological evidence from the southern part of the Strzelin Massif, SW Poland. Geological Quarterly, 54 (3): 301-324.

Oliver G.J.H., Corfu F., Krough T.E. (1993) U-Pb ages from SW Poland: evidence for a Caledonian suture zone between Baltica and Gondwana. Journal of the Geological Society of London, 150: 355-369.

Patočka F., Szczepański J. (1997) Geochemistry of quartzites from the eastern margin of the Bohemian Massif (the Hrubý Jesenik Mts. Devonian and the Strzelin crystalline massif): provenance and tectonic setting of deposition. Mineralogical Society of Poland, Special Papers, 9: 151-154.

Pietranik A., Waight T.E. (2008) Processes and sources during Late Variscan dioritic-tonalitic magmatism: insights from plagioclase chemistry (Gęsiniec Intrusion, NE Bohemian Massif, Poland). Journal of Petrology, 49 (9): 1619-1645.

Pin C., Rodriguez J. (2009) Comment on "Rheic Ocean ophiolitic remnants in southern Iberia questioned by SHRIMP U-Pb zircon ages on the Beja-Acebuches amphibolites" by A. Azor et al. Tectonics, 28, TC5013, doi:10.1029/2009TC002495.

Pin C., Santos Zalduegui J.F. (1997) Sequential separation of light rare earth elements, thorium and uranium by miniaturized extraction chromatography: application to isotopic analyses of silicate rocks. Analytica Chimica Acta, 339: 79-89.

Rudnick R.J., Gao S. (2005) Composition of the continental crust, pp. 1-64. In: The Crust (ed. R.J. Rudnick) Vol. 3 Treatise on geochemistry (eds. H.D. Holland and K.K. Turekian). Elsevier Pergamon, Oxford.

Schaltegger U. (1997) Magma pulses in the Central Variscan Belt: episodic melt generation and emplacement during lithospheric thinning. Terra Nova, 9: 242-245.

Schulmann K., Gayer R. (2000) A model for a continental accretionary wedge developed by oblique collision: the NE Bohemian Massif. Journal of the Geological Society of London, 157: 401-416.

Skácel J. (1989) On the Lugicum-Silesicum boundary (in Czech with English summary). Acta Universitatis Wratislaviensis, 1113, Prace Geologiczno-Mineralogiczne, 17: 45-55.

Stacey J.S., Kramers J.D. (1975) Approximation of terrestrial lead isotope evolution by a two-stage model. Earth and Planetary Science Letters, 26: 207-221.

Steiger R.H., Jäger E. (1977) Subcommission on geochronology: convention on the use of decay constants in geo- and cosmochronology. Earth and Planetary Science Letters, 36: 359-362.

Stull R.J. (1979) Mantled feldspars and synneusis. American Mineralogist, 64: 514-518.

Suess F.E. (1912) Die moravischen Fenster und ihre Beziehung zum Grundgebirge des Hohen Gesenke. Denkschriften Österreich. Akademie zur Wissenschaft, Mathematisch-Naturwissenschaftliche Klasse, 88: 541-631.

Suess F.E. (1926) Intrusionstektonik und Wandertektonik im variszischen Gebirge. Borntraeger, Berlin. 
Taylor S.R., Mc Lennan S.M. (1985) The Continental Crust: its Composition and Evolution; an Examination of the Geochemical Record Preserved in Sedimentary Rocks. Blackwell, Oxford.

Thompson R.N. (1982) British Tertiary volcanic province. Scottish Journal of Geology, 18: 49-107.

Turniak K., Tichomirova M., Bombach K. (2005) Zircon Pb evaporation ages of granitoids from the Strzegom-Sobótka Massif (SW Poland). Mineralogical Society of Poland, Special Papers, 25: 241-245.

Turniak K., Tichomirova M., Bombach K. (2006) Pb-evaporation zircon ages of post-tectonic granitoids from the Strzelin Massif (SW Poland). Mineralogia Polonica, Special Papers, 29: 212-215.

Vance J.A. (1969) On synneusis. Contributions to Mineralogy and Petrology, 24: 7-29.
Vernon R.H. (2004) A Practical Guide to Rock Microstructure. Cambridge University Press.

Whitney D.L., Evans B.W. (2010) Abbreviations for names of rock-forming minerals. American Mineralogist, 95: 185-187.

Wiedenbeck M., Allé P., Corfu F., Griffin W.L., Meier M., Oberli F., von Quadt A., Roddick J.C., Spiegel W. (1995) Three natural zircon standards for U-Th-Pb, Lu-Hf, trace element and REE analyses. Geostandards Newsletter, 19: 1-23.

Williams I.S. (1998) U-Th-Pb geochronology by ion microprobe. Reviews in Economic Geology, 7: 1-35.

Żelaźniewicz A., Aleksandrowski P. (2008) Tectonic subdivision of Poland: southwestern Poland (in Polish with English summary). Przegląd Geolologiczny, 56: 904-911. 